\title{
A Review of Health Hazards Associated with Rainwater Harvested from Green, Conventional and Photovoltaic Rooftops
}

\author{
Gilbert Osayemwenre and Otolorin Adelaja Osibote
}

\begin{abstract}
The world is experiencing a decrease in the volume of global freshwater. Most countries are faced with both freshwater and energy crises. For these reasons, countries are encouraging the use of renewable energy systems such as photovoltaic (PV) modules/panels. Regarding water, there is a need to enhance domestic rainwater harvesting process in informal (low-income) settlements and rural areas. However, because of the contamination, such harvested rainwater may pose a health hazard to its consumers in instances involving photovoltaic roofs. When photovoltaic modules degrade, cracks and delamination may occur in some of the modules. PV modules have the potential, therefore, of producing and leaching toxicants/metals into the rainwater harvested from such PV panels. At a certain degree of contamination water may become non-potable since it can cause a problem upon consumption. This challenge requires a detailed review investigation to reveal the actual effect of the continuous use of the rainwater as mentioned earlier and its possible solution. To achieve this, a review of what has been done in this area is presented and analysed. This study combines the effect of contamination of rainwater harvested from multiple roof types, such as conventional roof, green roof, integrated roof and PV roof of newly installed panels. This study is vital in the sense that while the health impact of a newly installed PV system can easily be controlled by merely avoiding the use of rainwater harvested during the infant stage of its installation, the same cannot be said of the later stage, as perpetual avoidance may be impossible.
\end{abstract}

Index Terms-Water quality, harvesting water, microbiological, Rainwater harvesting system (RWHS), runoff, Physico-chemical, Thin-film solar cell.

\section{INTRODUCTION}

The human right to water qualifies everybody for adequate, protected, worthy, genuinely available, and reasonable water for individual and household use [1]. A sufficient volume of safe water is essential for healthy living, to reduce the danger of water-related sickness, and to accommodate drinking, cooking, individual, and local cleanliness necessities. A lack of water storage can lead to hazardous water supplies and conceivably impact on the wellbeing and safety of human. Arrangements for safe drinking water is essential for the assurance of general wellbeing. There are few surface water sources in the world. The local groundwater around the globe is usually very shallow, which makes them vulnerable to

Manuscript received April 1, 2021; revised July 2, 2021. This work was supported by the Cape Peninsula University of Technology, South Africa.

The authors are with the Department of Mathematics and Physics, Faculty of Applied Sciences, Cape Peninsula University of Technology, Cape Town, South Africa (e-mail: osayemwenreg@cput.ac.za, osibotea@cput.ac.za). contamination. The abuse of underground water has lad ocean water interruption, and the reckless release of human waste has rendered ground waters unsuitable for drinking use at numerous spots. The implication of this is that circumstances have caused water specialists to consider options that incorporate harvested rainwater and desalination of seawater. There are a few misunderstandings about the utilisation of rainwater as drinking water and applying chlorination to make it suitable for drinking. Most commonly known water treatment chemicals can cause air pollution [2]; an example is the nasty smell and taste of chlorination. Chlorination is a treatment intended to prevent waterborne sicknesses [1], [2].

Although there are no common principles or standards for rainwater gathering and its utilisation, in 1999, United States of America federal and state agencies put in place regulations for household water collecting and its activity [1], [3]. Such regulations should include residential unit rainwater gathering for household use, but other uses of rainwater including the groundwater are not talked about. However, there is a requirement for groundwater systems and the utilisation of stored water in rural areas. According to Moskowitz [2], the opportunity has always been there for the people charged with the responsibility of water management to think about alternative arrangements. Consequently, any means of getting rainwater from a building is crucial and most be encouraged and people must be protected from harmful contents.

There are health hazards associated with the use of degraded PV modules [1], [4]. The initial aim of solar module manufacturers was to recycle old PV modules after failure. However, recycling has suffered because there are not enough places to recycle old PV modules. Secondly, the economic value is too insignificant as the volume of old PV modules is too trivial. These points are supported by the experience of the SolarWorld, a company which manufactures PV modules, but could not collect enough old modules to make it worthwhile, so now there is no market value in recycling. One of the reasons for this is that most modules installed over the years have exceeded their predicted life span of 30 years and are still performing fine [1], [2]. Despite the point raised by Mason [1], PV manufacturers are compelled by the Silicon Valley Toxics Coalition (SVTC) to take responsibility for environmental and communities safe during and after the production process and [2], [5]. In reality, the health impact of Si PV and Thin-film PV at the end of their cycles are not taken into consideration, and this is a drawback. Therefore, the need for the researcher to investigate the hazardous nature of 
delaminated PV modules when in contact with rainwater.

\section{A. Background of Study}

Throughout the world, water quality is one of the most researched topics, especially regarding the collection of rainwater. The concern in this regard is its hazardous nature when it is polluted which can be harmful to the health of consumers. Research has been conducted on the potability of rainwater in relation to the collection and storage system design type [6]. The extent of the impact the catchment and storage system have on rainwater harvesting still needs to be explored. This is why Campisano et al.'s [6] review aimed to establish a robust database associated with water quality management systems. Teston et al. [7] conducted a review regarding rainwater consumption from buildings in Brazil. This type of work should be conducted in other countries if we are to have a robust data-based system reflecting different continents.

In building a house, one has to comply with necessary legal and safety requirements laid down by experts to address environmental safety and the living comfort of the building. However, there are no regulations regarding the safety of rainwater collection from a roof with PV cells. Because of water challenges recurring in different parts of the world, the photovoltaic roof system is gaining attention in harvesting water. There is a concern in this regard due to the presence of chemical substances that can leach from PV in the long-term. Possible chemical leaching from building rooftop materials at the end of their life cycle also represents a problem, especially when definite knowledge about the hazardous nature and the resultant risk factors are not known. Storing rooftop water for long-term use when the building contains a photovoltaic module that has a degraded portion is not satisfactory. The risk associated with consumption of rainwater gathered from a roof with PV cells where leaching is occurring as a result of degradation has not been entirely ascertained. The more people become aware of the chemical contents of building material, the better. This will enable people to access the safety measures required to minimise potential risks. The idea of Building Coordinated PV (BIPV) would ensure that PV cells must be considered as a vital building component and a structured segment like rooftop tiles, blocks, or cement. At present, there is no commitment from the provider of solar cells to give data to clients about compound constituents. In some nations as Austria and the USA there are guidelines for a building material that can be used; however, the utilisation of PV in a building is moderately new, therefore environmental guidelines do not exist [8], [9].

The main challenge of PV users, especially in Africa, is low-quality modules which in most cases are readily available everywhere, hence the need to look at the health implication of these PV modules when they begin to degrade. This is important because during the production process, manufacturers use hazardous chemicals for various purposes such as cleaning and purification of the surface [10], [11]. Studies have revealed that these chemicals include hydrochloric acid, nitric acid, hydrogen fluoride, 1,1,1-trichloroethane, acetone and sulphuric acid. Thin-film PV modules contain more toxic materials than conventional silicon PV modules [10], [12]. As PV modules begin to degrade and with continued exposure to harsh environmental conditions, moisture and water ingress occurs. When delamination of the PV module's protective layers occurs, it contaminates any rainwater harvested from it [12]. If such water is consumed or used for domestic purposes it can affect human health negatively. However, this is not to discourage the use of PV modules, but to provide a detailed report of the disadvantage of the continuous use of PV modules that are degraded in relation to rainwater collection and uses.

PV modules are still the best form of renewable energy source, with an estimated life-cycle emission of $0.07 \mathrm{~kg}$ to $0.18 \mathrm{~kg}$ and $0.08 \mathrm{~kg}$ to $0.2 \mathrm{~kg}$ of carbon dioxide equivalents per kilowatt-hour for silicon and concentrates solar panels respectively [11], [13], [14]. These emission rates are far less than those from natural gas and coal which are $0.6 \mathrm{~kg}$ to $2 \mathrm{~kg}$ and $1.4 \mathrm{~kg}$ to $3.6 \mathrm{~kg}$, respectively [11]. An approximation of 11.7 to $91 \%$ reduction in emission rate can be achieved when fossil fuel can be replaced completely by PV modules [11], [14]. These reports by previous authors demonstrate the need to encourage renewable energy sources to reduce the greenhouse gas effect and drastically cut down on the emission of carbon dioxide.

The most commonly used material during the installation of PV modules on a house roof is lead [13], [14]. Lead is used for wiring and soldering processes (solder coated copper strips) and is one of the most toxic substances used in PV installation process. Research has shown that high concentrations of lead (i.e. exceeds $30 \%$ of the allowable for toxicity characteristic leaching procedure (TCLP) as per US EPA [14] in drinking water is toxic to the central nervous system, endocrine system, cardiovascular system, and kidneys [15], [16]. Here we review some primary health and safety issues associating with roofing type, rainwater-harvesting $(\mathrm{RWH})$ systems, $\mathrm{PV}$ landfill and release of toxic metals from PV. The newest form of roofing is a green based roof within the context of green residential buildings [17].

\section{SustainABLE RoOFING}

\section{A. Green Roof}

The conventional method of house roofing has gradually been replaced by a more energy-friendly roofing systems known as green roofing [14], [15]. This roofing makes use of vegetation in an artificial medium and waterproof membrane [16], [17], so any roofing system that is partially or fully lined with a particular plant in a greening medium where vegetation grows on a water-resistant medium is known as a green roof. A green roof is referred to as a roof that is essential to diminish the effect of land scarcity [17], [18]. As land becomes scarce and development is inevitable in meeting the growing need of the current population, green spaces are necessary to enhance the quality of life in any nation [18]. One promising option is the greening of buildings by implementing green roofs and green walls [17], [19]. This increases the percentage of greenery in an urban built-up area and brings back the vanishing urban green space [20]. The definition of green roof is the creation of 
"green spaces on top of a human-made structure, and in all cases, the plants are not planted on the 'ground" [21]. There are two main types of green roofs established in Europe, namely extensive and intensive [22]-[26]. Extensive green roofs have a substrate layer with a maximum depth of about $150 \mathrm{~mm}$, often planted with Sedum species as a significant part of the vegetation while the intensive green roofs have a substrate layer with a depth of more than $170 \mathrm{~mm}$ a weight range of $171 \mathrm{~kg}$ to $345 \mathrm{~kg}$, with grasses, perennial herbs and shrubs making up the main constituents of the vegetation [27]-[29]. Previous research shows that green roofs have numerous environmental benefits such as reduced flood risk, improved rainwater runoff quality [27], [28], mitigation of urban heat (heat island), energy-saving for the building, and provision of a habitat for urban wildlife [27], [29].

In green roofing, it seems as an associate mean of the existing rooftop where there is growing vegetation in place. In real green roofing, the soil has to be on a water-resisting membrane to ensure the safety of the other components of the roof. The ideal of green roofing is not to eliminate the conventional roof system but to have a roofing system that can produce both energy and potable water for household use to mitigate the effect of water scarcity that exists in many countries. Rainwater harvesting is an old practice, especially for rural dwellers, while most urban dwellers ignore these practices. Nevertheless, the reality of water scarcity is gradually prompting more urban dwellers to harvest rainwater and to design green roofs that can be used for potable water harvesting systems [26]. Rural communities might not be able to embrace intensive and extensive [29] types of roofing because of their complexity and high cost. This is not to say that rainwater harvesting cannot be utilised in a rural area; though some sites have natural water storage, these sources can dry up, and the tedious process of fetching such water can prove to be challenging and time consuming.

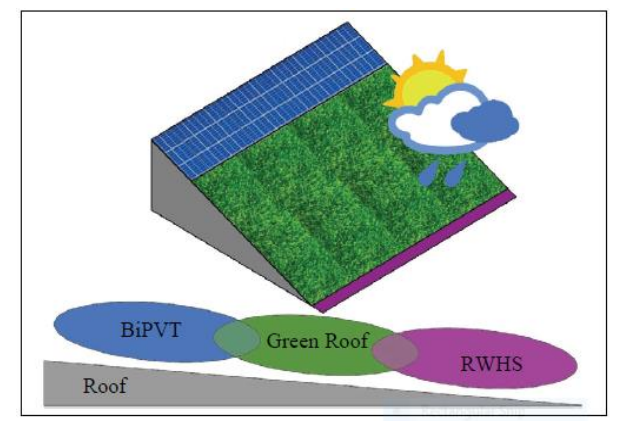

(a)

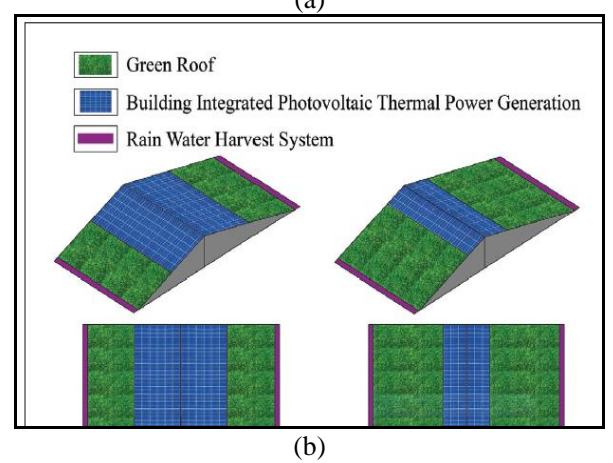

Fig. 1. Building roof design with a green roof with integrated photovoltaics module a), vertical view showing the thermal power generation (adapted from (a) [27], (b) [27])
The current type of green roof is believed to be effective in harvesting potable clean water since the source of the water is known to be the cleanest source of water [29]. However, the cleanness of such water is dependent on the method of collection, environmental conditions, storage material, degree of atmospheric pollution and roofing material. Figure 1 (a \& b) presents a vertical view of green rooftop system partially covered by photovoltaic (PV) modules. This literature review will focus on green roofs with PV modules and roofs with PV modules only.

\section{B. Contaminants - Pathogens and Chemicals}

Levsen et al. [30] pointed out the importance of harvesting rainwater. The release of atmospheric precipitation on the earth is the most common source of runoff water [31]-[34]. It is naturally impossible to have runoff water without some degree of contamination [35]. The contamination level depends on the environment aside from the collection materials [29] and [36]-[41]. For example, Polkowska et al. [42] found high levels of pesticides from rooftop harvested rainwater compared to water directly from precipitation. The authors' research was conducted in the city of Gdansk in Poland hence in an urban setting, and the findings could have been different in another city [38], [43]-[45]. One of the conclusions of their study was the need to do more studies on this subject and for recommendations to be drawn up in this regard [36], [45].

Polkowska et al. [42] sought to distinguish between pesticides and toxicity in the water samples analysed. In this study no chemical was added for any reason and the water was analysed in the laboratory straight after harvesting [45]. The result of pesticide and toxicity of the tested water showed variation in the pesticide and toxicity of each rooftop [46]. About $50 \%$ of the tests were found to be non-toxic compared to the WHO standards [47]. Only $20 \%$ of the results exceeded the safety guidelines recommended by WHO. There was some amount of halogenated compound found as well, although the organohalogens quantities could not be directly linked to total toxicity recorded in the study [48]. Thus, one can assume that hydrocarbons and organohalogens can result from rooftop material and that PV installation material can be the source of these contaminants. The presence of pesticides can be a result of airborne pollution but the other toxic (organohalogen content) can be primarily due to the rooftop and collecting materials.

Polkowska et al. [42] presented findings on both drinking and domestic water in terms of disease risks which are usually limited in most related studies [45], [49]-[51]. With reference to Austria as one of the few countries that have enacted a programme to preserve natural water supplies (Australia Capital Territory Think Water, Act

Water Strategy) following the 2001 to 2009 drought [45], [52], [53]. It is obvious that standard and working models are needed to achieve the task of any enacted water management programme. This is why it is very challenging to develop appropriate designs of water collection systems for house usage in term of quality and health standards, and which promote sustainable water usage and elimination of waterborne pathogens [51]. Examples of studies of water contaminants from rooftop rain harvesting are those of 
Polkowska [54] and Grynkiewicz et al. [55] (Table I).

TABLE I: DIFFERENT ROOFING MATERIALS AND CHEMICAL CONTAMINANTS FOUND IN RAINWATER RUNOFF, GDANSK, POLAND [54], [55]

\begin{tabular}{|c|c|c|c|}
\hline $\mathrm{s} / \mathrm{n}$ & Authors & $\begin{array}{l}\text { Roofing } \\
\text { material }\end{array}$ & concentration [ng/l] \\
\hline 1 & [54] & Tar paper & $\begin{array}{l}\text { aldrine }(6,020), \text { methoxychlor } \\
(430), \text { heptachlor epoxide } \\
(19,970), \text { p,p'- DDD }(520), \text { o,p'- } \\
\text { DDE (540), o,p'- DDD (340), } \\
\text { p,p'- DDE (450), o,p'- DDT }(190) \text {, } \\
\text { p,p'- DDT (370), } \alpha \text { - HCH }(200), \gamma \\
\text { - HCH (400), propazine }(1,070), \\
\text { terbutylazine (120) }\end{array}$ \\
\hline 2 & [55] & $\begin{array}{l}\text { Ceramic } \\
\text { roofing tiles }\end{array}$ & $\begin{array}{l}\text { aldrine (130), methoxychlor (430), } \\
\text { heptachlor epoxide }(430), \text { p,p'- } \\
\text { DDD }(4,610), \text { o,p'- DDE }(2,800) \text {, } \\
\text { o,p'- DDD }(1,210), \text { p,p'- DDE } \\
(1,360), \text { p,p'- DDT }(1,080), \alpha- \\
\text { HCH }(740), \gamma \text { - HCH }(600), \\
\text { propazine }(1,110), \text { terbutylazine } \\
(120), \text { bromophos }(2,720)\end{array}$ \\
\hline 3 & $\begin{array}{l}{[53],} \\
{[55]}\end{array}$ & $\begin{array}{l}\text { Asbestos } \\
\text { cement } \\
\text { corrugated } \\
\text { sheets }\end{array}$ & $\begin{array}{l}\text { aldrine (610), methoxychlor (130), } \\
\text { heptachlor epoxide }(14,540), \mathrm{p}, \mathrm{p} \text { - } \\
\text { DDD (500), o,p'- DDE (4,640), } \\
\text { o,p'- DDD (7,040), p,p'- DDE } \\
(1,040), \text { o,p'- DDT }(750), \mathrm{p}, \mathrm{p} \text { - } \\
\text { DDT }(8,460), \alpha \text { - HCH }(460), \gamma \text { - } \\
\text { HCH }(840), \text { atrazine }(1,210), \\
\text { terbutylazine (130), bromophos } \\
(310)\end{array}$ \\
\hline 4 & [54] & $\begin{array}{l}\text { Metal roofing } \\
\text { tiles }\end{array}$ & $\begin{array}{l}\text { Heptachlor epoxide(1,640), o,p'- } \\
\text { DDE (920), o,p'- DDD }(1,890), \\
\text { p,p'- DDE (680), o,p'- DDT (490), } \\
\text { p,p'- DDT (830), } \alpha \text { - HCH }(320), \gamma \\
\text { - HCH (500), propazine }(400), \\
\text { bromophos }(4,912), \text { atrazine } \\
(2,980), \text { simazine }(620), \text { malathion } \\
(1,960), \text { fenitrothion }(630), \\
\text { chlorfenvinfos (180) }\end{array}$ \\
\hline 6 & [53] & $\begin{array}{l}\text { Bituminous } \\
\text { membrane }\end{array}$ & $\begin{array}{l}\text { heptachlor epoxide }(1,680) \\
\text { bromophos }(50)\end{array}$ \\
\hline 7 & [53] & PTFE & bromophos (40) \\
\hline
\end{tabular}

Table I shows different chemicals associated with different roofing material, as exposure time continues, by virtue of redox reaction chemical decomposition can occur. This is expected to leach different heavy metals from each roofing material especially close to the end of their life span. According to Polkowska [54], the concentrations of $\mathrm{Zn}^{2+}$, $\mathrm{Pb}^{2+}, \mathrm{Cu}^{2+}$ and $\mathrm{Cd}^{2+}$ from rain and runoff water samples of different roofing material differs. As expected, the heavy metal concentration for the runoff was higher than rainwater alone, due to possible leaching from the roof materials. Traces of $\mathrm{Zn} 2+, \mathrm{Pb} 2+$ was found in both runoff and rainwater. At first, one would suspect $\mathrm{Zn}$ to leach from runoff water from an asbestos cement roof [53], [54]. However, this was not the case because the $\mathrm{Zn}$ content originates from the delivery pipe. $\mathrm{A} \mathrm{Pb}$ content of $12 \mu \mathrm{g} / 1$ was discovered in rooftops covered with thermally bonded tar paper. This rise in $\mathrm{Pb}$ content can be linked-to leaching of $\mathrm{Pb}$ from the building roof. The highest level of organochlorine pesticides corresponding to $20 \mathrm{ng} / \mathrm{l}$ was found in the Pryzymorze area of Gdansk associated with tar paper material. The metal tile roof had the highest concentration of organonitrogen and organophosphorus pesticides of $52 \mathrm{ng} / \mathrm{l}$.

These studies support the view that most rooftop material plays a significant role in the quality of water harvested from such a building. Therefore, roof material, catchment type, storage tank and length of storage must be defined for accurate analysis of water quality, otherwise quality of water will just be guesswork which will send the wrong information about the integrity of such water. The section below summarized some findings relevant to water runoff contaminations in rainwater harvesting (RWH) systems and their source [55]. The possible health risks are analysed and potential prevention and treatment that can help eliminate such contamination is highlighted.

\section{QUALITY CONSIDERATIONS OF WATER}

\section{A. Water Quality from RWH Systems}

According to Hofman et al. [56], depending on application and the intended use of water, quality prerequisites may change and the quality of the collected water may shift in space and time. Abbasi and Abbasi [57] showed that the water quality of gathered water depends on numerous factors; this confirms the previous work by others like Hofman-Caris et al. [58], Sammut et al. [59] and WHO [60]. Their audit of water quality work focused on RWH systems and investigated the following forms of contaminants: i) chemical, ii) microbiological, and iii) physical. The source of contamination was also examined. The first source of contamination is the atmosphere; this starts immediately water raindrops leave the clouds, either as a particle or as solutes. Falling rainwater droplets can absorb any of the following: sulfate, nitrite, and carbon dioxide, usually in gaseous form. Additionally, rainwater might acquire pesticides from the air or splashes before it is collected. Hence there is a need to compare RWH quality with drinking water safety criteria for accountability purposes. Secondly, the surface of a rooftop was identified by Abassi and Abbasi [57] as a hotspot for toxins. Because rooftop harvested water can be affected by the kind of material used for the roofing, special attention has to be paid to green roofing and PV rooftops. Unfortunately, the research done on PV roofs is minimal compared to water harvested from other conventional housetop roofs. Thirdly, microbiological contamination can occur as a result of soil, leaves, faecal material from both living and dead creatures on the rooftop, and airborne microorganisms. For better understanding of microbiological contamination Table II is a comprehensive analysis as presented by Abassi and Abassi [57] of research on water quality from roof RWH. The analysis is followed by proposals to help control water quality in each case.

\section{B. Physico-Chemical Water Quality}

Marinoski et al. [61] and Ghisi et al. [62] works has some useful summary of previous findings regarding water quality. A summary of physico-chemical water parameters works on RWH water is presented in Table II. The category of physico-chemical includes the metallic contaminants and their concentration, the turbidity and the $\mathrm{pH}$ value of the harvested water. These parametric data are crucial in analysing the suitability of water for drinking. In Table IV the $\mathrm{pH}$ ranges reflected range from 6 to 9 as expected since 
rainwater is classified as soft water. The table presents the inconsistency of water quality and the impact of roof material on the harvested water. Findings from multiple works presented in Table III indicate that all the inorganic material concentration are lower than the acceptable level permitted in drinking water according to Netherlands water standards [63] Table IV shows that all the metallic substances are of lower concentration compared to the drinking water standards except for lead.

\section{Microbiological Water Quality}

The most frequently analysed aspect of water is its microbiological quality due to extensive involvement of biological scientists in the field. Numerous data have been presented on the microbiological quality of water. These papers are of two types: the first are those that deal with human consumption of harvested rainwater, a common practice in developing nations [64]-[66]; the second are those that deal with rainwater harvesting for non-human consumption. Most articles report on and compare both types. Overall, the results prove that such water has good quality, while some warned of possible health complications [66]. The risk factors appear to be related to collection techniques, storage, and system maintenance. Another category of papers includes Hofman et al.'s [56] work related to non-potable rainwater collection in the Netherlands. All of this work shows the importance of water control and treatment to be sure that the microbiological parameters do not exceed acceptable levels. A summary of the quantities of microbiological features in rainwater after the first flush is given in Table V. A further concern is that when water is stored for long periods under specific temperatures, its microbiological parameters can increase. Thus, the contamination of water can occur either from the collection method or from the storage system [67]

In 2012, Dean and Hunter published a paper on human consumption of rainwater. Their work found that harvested water has acceptable quality except when inappropriate roofing material is used and there is poor maintenance. Dean and Hunter's [64] work was quite different from Hofman et al.'s [56] work which was on non-drinking water. The only reason why microbiological water quality was analysed by Hofman et al is because of human contact. This knowledge is useful for human safety and environmental concern. The summary of the work is seen in Table V. The microbiological parameter presented here can either come from surface contamination or from the storage tank because when the situation is favourable bacteria growth multiplies. However, Farreny et al. [67] show that rooftop microbial contaminations have a less harmful effect. Table III is a collection of data published in accredited journals on the physico-chemical quality of harvested rainwater in different nations [65], [68].

This segment deals with microbial origin how faecal indicator bacteria enter rainwater since it is initially pure in its original form. Consumption of pathogens contaminated rainwater is linked to disease outbreak, gastroenteritis infection, and acute risk of illness. Usually, rainwater does not contain any form of contamination, due to its formation that involves precipitation and condensation. On the other hand, harvested rainwater is not always without impurities due to collection methods, purity of the atmosphere, the purity of the rooftop, the nature of the storage tank [40], [69]. These various medium are capable of providing impurity into the harvested water, thereby deteriorate the purity of rainwater from its original state to household use. Majority of impurities are atmospherically related like dirt from wind, falling leaves, faecal from birds, insects and contaminated litter on the catchment [45], [70]. When the scenario describes above occur and such water is stored in the tank, the consumption of such water possess health issues to users. The possible accumulation of impurity that leads to the genesis of bioorganic is the cue reason to always maintain high hygiene in the storing of water in the tank. However, risks from these risks can be minimized through proper design and practice. Properly designed rainwater harvesting structures with easy catchments and tanks supported by using proper hygiene at position collection for use can provide limit risk factor below WHO recommended level, while a poorly designed and controlled machine can pose excessive health risks. Accumulated Microbial infection of rainwater indicated through E. Coli is quite not unusual, especially when such water samples collected quickly after rainfall [51], [71]. Some class of Pathogens recorded by [WHO] including Cryptosporidium, Giardia, Campylobacter, Vibrio, Salmonella, Shigella and Pseudomonas. However, the prevalence of pathogens is typically lower in rainwater than in unprotected floodwaters. Hence storage tanks are required to be covered. Some authors have argued that the presence of non-bacterial pathogens can be minimized when the storage water tank is covered [20], [71]. Different authors had shown that substantial decrease of microbial contamination is achievable during rainy seasons by regular washing of the catchments with pure water. This also prevents future occurrence of breeding sites for mosquitoes, including species that transmit dengue virus in storage tanks [47], [60], [70]. In summary, rainwater stored in tanks can be contaminated from faecal bacteria and pathogens from aerosol deposition, animal faecal, aside biofilms, and sediments [71]-[75]. Pathogens and indicator bacteria/microbial can be either ecology or pathogen originating from plumbing system converging rainwater from tanks [76]. Also not is known regarding kind of pathogen or microbial ecology originating inside pluming, tank, and the roofing material. According to Mendez et al., [77], different kinds and concentration of pathogens were found in rainwater stored in a tank of different roofing material. The roofing material considered are asphalt fiberglass shingle, metal, concrete title and green roof material. The best roofing material in term of low pathogens formation is metal roof [72], [78]. The pathogen impurities considered for this assessment are suspended solids, nutrients, metals, and Escherichia coli (E. coli) [77]-[81].

\section{Water Quality from Microbiological Assessment}

Hamdan [82] studied the microbiological effect of water and its implication for health, and the conclusion is similar to other authors' findings [83]-[85]. There are many sources of supplements and heavy metals in water gathering. Historically, the main strategies of RWH used were for 
drainage and dams to gather runoff, but in present-day RWH the roof serves as a major source of runoff [86]-[88]. Multiple studies have been conducted on the quality of water once it has been exposed to a surface, revealing substantial changes in quality. One of the most well-studied phenomena regarding the absorbing of climatic particles by water is that of acidic rain. Yaziz et al. [86] found that the $\mathrm{pH}$ of rainwater collected for their study was 5.9 which is below the World Health Organization drinking water requirement of 6.5 to 8.5 (Table VIa). Tables VIa and Table VIb show that many other poisons metals have been measured in water because of their nearness within the atmospheric pollution.

TABLE II: PHYSICOCHEMICAL PARAMETERS IN HARVESTED RAINWATER AFTER FIRST FLUSH

\begin{tabular}{|c|c|c|c|c|c|c|c|}
\hline Location & $\mathrm{pH}$ & $\mathrm{EC}(\mu \mathrm{S} / \mathrm{cm})$ & Turbidity (NTU) & $\begin{array}{l}\text { TOC } \\
(\mathrm{mg} / \mathrm{L})\end{array}$ & $\begin{array}{l}\mathrm{TH} \\
(\mathrm{mmol} / \mathrm{l})\end{array}$ & Sample $^{1,2}$ & Reference \\
\hline $\begin{array}{l}\text { Seine Maritime, } \\
\text { France }\end{array}$ & $\begin{array}{l}6.9-8.9 \\
7.1-8.7\end{array}$ & $\begin{array}{l}117-188 \\
119-197\end{array}$ & $\begin{array}{l}0.8-2.0 \\
1.3\end{array}$ & $\begin{array}{l}<0.03 \\
<0.03\end{array}$ & $\begin{array}{l}0.3-0.8 \\
0.4-0.7\end{array}$ & $\begin{array}{l}\mathrm{T} \\
\mathrm{PoU}\end{array}$ & [68] \\
\hline Ain, France & $\begin{array}{l}4.5-6.5 \\
4.2-6.4 \\
\end{array}$ & $\begin{array}{l}10-32 \\
18-31 \\
\end{array}$ & $\begin{array}{l}0.7-3.4 \\
0.6-1.8 \\
\end{array}$ & $\begin{array}{l}166-8800 \\
170-3500 \\
\end{array}$ & $\begin{array}{l}<0.08-0.1 \\
<0.05-0.1 \\
\end{array}$ & $\begin{array}{l}\mathrm{T} \\
\mathrm{PoU} \\
\end{array}$ & [68] \\
\hline $\begin{array}{l}\text { Île-de-France, } \\
\text { France }\end{array}$ & $\begin{array}{l}1.2 \\
1.2\end{array}$ & $\begin{array}{l}32 \\
24 \\
\end{array}$ & $\begin{array}{l}1.7 \\
1.2\end{array}$ & $\begin{array}{l}1.5 \\
0.1\end{array}$ & $\begin{array}{l}0.04 \\
0.04\end{array}$ & $\begin{array}{l}\mathrm{T} \\
\mathrm{PoU}\end{array}$ & [68] \\
\hline $\begin{array}{l}\text { Rual Village, } \\
\text { France (SW) }\end{array}$ & $6.5(5.6-10.4)$ & $\begin{array}{l}56.2 \\
(13.5-235)\end{array}$ & $2.4(0.5-6.1)$ & $2.3(0.5-5.1)$ & $\begin{array}{l}0.16 \\
(<0.01-0.58)\end{array}$ & $\mathrm{T}$ & [69] \\
\hline $\begin{array}{l}\text { Sidney (4 sties), } \\
\text { Australia }\end{array}$ & $6.60 \pm 0.50$ & $62.2 \pm 54.5$ & $2.96 \pm 6.16$ & No data & $0.24 \pm 0.21$ & $\mathrm{~T}$ & [70] \\
\hline $\begin{array}{ll}\text { Seoul(3 tanks). } \\
\text { Korea }\end{array}$ & $\begin{array}{l}7.04(6.8-8.2) \\
8.71(7.7-9.9) \\
8.56(6.7-9.7)\end{array}$ & $\begin{array}{l}45(42-56) \\
88(75-109) \\
286(152-428\end{array}$ & $\begin{array}{l}3.4(1.4-10.8) \\
5.7(0.41-8.56) \\
4.90(1.31-11)\end{array}$ & No data & No data & $\begin{array}{l}\mathrm{T} \\
\mathrm{T} \\
\mathrm{T}\end{array}$ & [71] \\
\hline $\begin{array}{l}\text { Ballinabrannagh } \\
\text { Ireland SE }\end{array}$ & $\begin{array}{l}7.21 \\
(6.26-8.21)\end{array}$ & No data & $1.11(0.0-4.60)$ & No data & $0.35(0.1-0.6)$ & $\mathrm{T}$ & [72] \\
\hline Exeter,UK & $7.6-10.4$ & $43.5-261$ & $0.3-2.8$ & No data & $0.16-0.27$ & $\mathrm{~T}$ & [73] \\
\hline $\begin{array}{l}\text { UAB University } \\
\text { Barcelona, Spain }\end{array}$ & $7.59 \pm 0.07$ & $85.0 \pm 10.0$ & No data & $11.6 \pm 1.7$ & No data & $\mathrm{T}, 4$ roofs & [74] \\
\hline
\end{tabular}

TABLE III: INORGANIC PARAMETERS IN HARVESTED RAINWATER AFTER FIRST FLUSH

\begin{tabular}{|c|c|c|c|c|c|c|c|}
\hline Location & $\begin{array}{l}\mathrm{Cl}^{-} \\
\mathrm{mg} / \mathrm{L}\end{array}$ & $\begin{array}{l}\mathrm{SO}_{4}^{2-} \\
\mathrm{mg} / \mathrm{L}\end{array}$ & $\begin{array}{l}\mathrm{NO}_{2}^{-} \\
\mathrm{mg} \mathrm{N} / \mathrm{L}\end{array}$ & $\begin{array}{l}\mathrm{NO}_{3}^{-} \\
\mathrm{mg} \mathrm{N} / \mathrm{L}\end{array}$ & $\begin{array}{l}\mathrm{Na}^{+} \\
\mathrm{mg} / \mathrm{L}\end{array}$ & Sample ${ }^{1,2}$ & Reference \\
\hline Seoul, Korea & No data & $\begin{array}{l}0.1-1.5 \\
0.1-0.8 \\
0.1-0.5 \\
0.0-0.1\end{array}$ & No data & $\begin{array}{l}0.06 \\
0.06 \\
0.02 \\
0.00\end{array}$ & No data & $\begin{array}{l}\text { T,Wd } \\
\text { T,Con } \\
\text { T,Clay } \\
\text { T,GSteel }\end{array}$ & [75] \\
\hline $\begin{array}{l}\text { Ballinabrannagh } \\
\text { Ireland SE }\end{array}$ & $\begin{array}{l}5.06 \\
(1.50-2.49)\end{array}$ & $7.50(0.0-31.7)$ & $0.01(0.0-0.15)$ & $0.33(0.0-0.64)$ & $4.60(0.0-8.6)$ & $\mathrm{T}$ & {$[74]$} \\
\hline Exeter,UK & $3-28$ & No data & $<0.01-0.22$ & $1.32-17.74$ & $2.8-4.3$ & $\mathrm{~T}$ & [75] \\
\hline $\begin{array}{l}\text { UAB University } \\
\text { Barcelona, Spain }\end{array}$ & $8.86+2.38$ & $3.54 \pm 0.39$ & $0.040 \pm 0.015$ & $0.395 \pm 0.059$ & No data & $\mathrm{T}, 4$ roofs & {$[76]$} \\
\hline $\begin{array}{l}\text { Austin, Texas } \\
\text { USA }\end{array}$ & No data & No data & $\begin{array}{l}0.03 \\
0.02 \\
0.03 \\
0.02 \\
0.03\end{array}$ & $\begin{array}{l}1.0 \\
1.1 \\
1.1 \\
1.1 \\
1.5\end{array}$ & No data & $\begin{array}{l}\text { T,Asph } \\
\text { T,AlZnStl } \\
\text { T,ConT } \\
\text { T,Bit } \\
\text { T,Green }\end{array}$ & [77] \\
\hline
\end{tabular}

TABLE IV: HEAVy METALS IN HARVESTED RAINWATER AFTER FIRST FLUSH

\begin{tabular}{|c|c|c|c|c|c|c|c|}
\hline Location & $\begin{array}{l}\text { Aluminium } \\
\mathrm{mg} / \mathrm{L}\end{array}$ & $\begin{array}{l}\text { Copper } \\
\mathrm{mg} / \mathrm{L}\end{array}$ & $\begin{array}{l}\text { Lead } \\
\mathrm{mg} \mathrm{N} / \mathrm{L}\end{array}$ & $\begin{array}{l}\text { Zinc } \\
\mathrm{mg} \mathrm{N} / \mathrm{L}\end{array}$ & $\begin{array}{l}\text { Iron } \\
\mathrm{mg} / \mathrm{L}\end{array}$ & Sample ${ }^{1,2}$ & Reference \\
\hline $\begin{array}{l}\text { Sidney (4 sites) } \\
\text { Australia }\end{array}$ & $0.115 \pm 0.143$ & $0.221 \pm 0.294$ & $0.011 \pm 0.013$ & $2.63 \pm 2.2$ & No data & $\mathrm{T}$ & [70] \\
\hline Seoul, Korea & $\begin{array}{l}0.043 \\
0.099 \\
0.036 \\
0.033 \\
\end{array}$ & $\begin{array}{l}0.009 \\
0.012 \\
0.015 \\
0.016 \\
\end{array}$ & $\begin{array}{l}0.003 \\
0.005 \\
0.003 \\
0.003 \\
\end{array}$ & $\begin{array}{l}0.018 \\
0.038 \\
0.019 \\
0.074 \\
\end{array}$ & $\begin{array}{l}0.023 \\
0.048 \\
0.024 \\
0.027\end{array}$ & $\begin{array}{l}\text { T,Wd } \\
\text { T,Con } \\
\text { T,Clay } \\
\text { T,GSteel }\end{array}$ & [72] \\
\hline $\begin{array}{l}\text { Ballinabrannagh } \\
\text { Ireland SE }\end{array}$ & No data & No data & $\begin{array}{l}0.002(0.0-0.025 \\
0\end{array}$ & No data & $0.022(0.0-0.095)$ & $\mathrm{T}$ & [74] \\
\hline Exeter,UK & $0.080-0.108$ & $0.218-0.290$ & $0.026-0.064$ & $0.193-0.480$ & $0.009-0.027$ & $\mathrm{~T}$ & [75] \\
\hline
\end{tabular}

TABLE V: MiCROBIOLOGICAL PARAMETERS IN HARVESTED RAINWATER AFTER FIRST FLUSH

\begin{tabular}{|c|c|c|c|c|c|c|}
\hline Location & $\begin{array}{l}\text { Total/Faecal } \\
\text { Coliforms } \\
\text { N/100ml }\end{array}$ & $\begin{array}{l}\text { E. Coli } \\
\text { N/100ml }\end{array}$ & $\begin{array}{l}\text { Enterococci } \\
\mathrm{N} / 100 \mathrm{ml}\end{array}$ & $\begin{array}{l}\mathrm{PC} 22^{\circ} \mathrm{C} / \mathrm{PC} 37^{\circ} \mathrm{C} \\
\mathrm{N} / \mathrm{ml}\end{array}$ & Sample $^{1,2}$ & Reference \\
\hline Seine Maritime, France & $\begin{array}{l}30-1,800 /- \text { and } \\
\text { illegilble results }\end{array}$ & No data & No data & $\begin{array}{l}56-480 / 40-450 \text { and } \\
\text { illegilble results }\end{array}$ & $\begin{array}{l}\mathrm{T} \\
\mathrm{PoU}\end{array}$ & {$[68]$} \\
\hline Ain, France & $\begin{array}{l}<30-230 /- \\
12-92 /-\end{array}$ & No data & No data & $\begin{array}{l}133-8,800 / 3-10,400 \\
170-3,500 / 6-5,000\end{array}$ & $\begin{array}{l}\mathrm{T} \\
\mathrm{PoU}\end{array}$ & {$[68]$} \\
\hline Île-de-France, France & $\begin{array}{l}1200 /- \\
1200 /-\end{array}$ & No data & No data & $\begin{array}{l}>100 / 400 \\
>100 / 250\end{array}$ & $\begin{array}{l}\mathrm{T} \\
\mathrm{PoU}\end{array}$ & {$[68]$} \\
\hline $\begin{array}{lll}\text { Rual Village, } & \text { France } \\
(\mathrm{SW}) & & \\
\end{array}$ & $40(<10->10,000)$ & $2(<10-5,500)$ & $45(<10->10,000)$ & $\begin{array}{l}10-632,000 / 25-368,00 \\
0\end{array}$ & $\mathrm{~T}$ & [69] \\
\hline Sidney (4 sites), Australia & $426 / 77$ & 11 & 12 & No data & $\mathrm{T}$ & [70] \\
\hline
\end{tabular}


In Table VIa the relationship between human and acid rain, is presented. Acidic rainfall depends on location and the number of acidic gasses released into the atmosphere. The results from Yaziz et al. [86] shows that vehicular traffick causes acidic rainfall. Also, northern Taiwan, where fossil fuel burning is high during the winter season showed more acidic rainfall of 5.9, according to Lee et al. [89]. In these highly polluted cities, the $\mathrm{pH}$ value is far less than the standard recommended by the World Health Organisation (WHO). The increase in acidic rain is due to the absorbing of polluted air by rain droplets. Therefore, there are other environmental issues associated with the heavily trafficked cities because of atmospheric and environmental pollution for details refer to Table VIa and VIb. In 2007 Melidis et al. [87] discovered that certain geographic factors and the nature of air pollution in an environment could increase the $\mathrm{pH}$ value of harvested water (Table VIa). In Table VIb, the presence of heavy metal pollution in water harvested from rainfall in different countries are displaced. The best part is that the reason behind the heavy metal observed in the rainfall water in these countries is explained. Lastly, Table VII presents an analysis of the results of these metallic pollutants in rainfall water against their recommended content in drinking water.

TABLE VIA: PHySICO-CHEMICAL CHARACTERISTICS OF RAINWATER. VALUES IN MG/L UNLESS OTHERWISE STATED

\begin{tabular}{|c|c|c|c|c|c|c|c|c|c|c|}
\hline \multirow[t]{2}{*}{ Reference } & \multirow[t]{2}{*}{ Location } & \multirow[t]{2}{*}{$\mathrm{pH}$} & Conductivity & \multirow{2}{*}{$\begin{array}{l}\text { Turbidity } \\
\text { (NTU) }\end{array}$} & \multirow[t]{2}{*}{$\mathrm{NH}_{4}{ }^{+}-\mathrm{N}$} & \multirow[t]{2}{*}{$\mathrm{NO}_{2}{ }^{-}-\mathrm{N}$} & \multirow[t]{2}{*}{$\mathrm{NO}_{3}{ }^{-} \mathrm{N}$} & Total & \multirow[t]{2}{*}{$\mathrm{PO}_{4}$} & \multirow[t]{2}{*}{$\mathrm{SO}_{4}^{2-}$} \\
\hline & & & $(\mu \mathrm{S} / \mathrm{cm})$ & & & & & Phosphorus & & \\
\hline [87] & Ile-Ife, Nigeria & 6.68 & 10.4 & 6.3 & 0.05 & & 0.86 & & & 0.5 \\
\hline [88] & Catalonia, Spain & 6.4 & 18 & & 0.41 & & 1.28 & & & 2.21 \\
\hline [89] & Nacogdoches, TX & 5.55 & 27.6 & & & & & & & \\
\hline [90] & Italy & 5.73 & 36.78 & & 1.61 & & 1.04 & & 0.008 & 7.12 \\
\hline [91] & $\begin{array}{l}\text { Kefalonia Island, } \\
\text { Greece }\end{array}$ & $8.31 *$ & $103^{*}$ & & $0.01 *$ & $0.013^{*}$ & $.269 *$ & & $0.09 *$ & $8.0^{*}$ \\
\hline [92] & Greenville, ME & 4.6 & 22.4 & & & & & & & \\
\hline [93] & $\begin{array}{l}\text { Armidale, } \\
\text { Australia (Rural) }\end{array}$ & 6.9 & 25 & 0.2 & & & 0.23 & & & \\
\hline [94] & $\begin{array}{l}\text { Armidale, } \\
\text { Australia } \\
\text { (Industrial) }\end{array}$ & 6.7 & 20 & 0.8 & & & 0.05 & & & \\
\hline
\end{tabular}

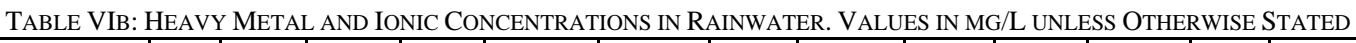

\begin{tabular}{|c|c|c|c|c|c|c|c|c|c|c|c|c|c|c|c|c|}
\hline Reference & Location & $\mathrm{Al}^{3+}$ & $\mathrm{Ca} 2+$ & $\mathrm{Cd}$ & $\mathrm{Cl}^{-}$ & $\mathrm{Cu} 2+$ & $\mathrm{Cr}$ & $\mathrm{Fe}$ & $\mathrm{HCO} 3-$ & $\mathrm{K}+$ & $\mathrm{Mg} 2+$ & $\mathrm{Mn} 2+$ & $\mathrm{Na}^{+}$ & $\mathrm{Ni}$ & $\mathrm{Pb} 2+$ & $\mathrm{Zn} 2+$ \\
\hline [95] & Ile-Ife, Nigeria & & 0.77 & & 1.7 & & & & 5.5 & 0.06 & 0.14 & & 0.21 & & & \\
\hline [96] & Catalonia, Spain & & 1.15 & & 1.01 & & & & & 0.2 & 0.1 & & 0.5 & & & \\
\hline [97] & Italy & & 1.86 & & 1.45 & & & & 1.8 & 0.44 & 0.44 & & 0.86 & & & \\
\hline [98] & Berkeley, CA & & & & & 0.005 & & & & & 0.07 & 0.003 & & & & 0.016 \\
\hline [99] & Xanthi, Greece & & 20 & & & & & & & 1.1 & 1.4 & & & & & \\
\hline
\end{tabular}

TABLE VII: SUMMARY OF DRINKING WATER STANDARDS (DWS) AND GUIDELINES (DWG) FROM VARIOUS AGENCIES [95]-[100]

\begin{tabular}{|c|c|c|c|c|c|}
\hline & $\begin{array}{l}\text { WHO, DWG } \\
\text { (WHO, 2008) }\end{array}$ & $\begin{array}{l}\text { USEPA Primary } \\
\text { DWS (USEPA, 2009) }\end{array}$ & $\begin{array}{l}\text { USEPA Secondary } \\
\text { DWS (USEPA, 2009) }\end{array}$ & $\begin{array}{l}\text { Australian DWG } \\
\text { (Australian, 2011) }\end{array}$ & $\begin{array}{l}\text { EU Directive DW } \\
\text { Guidelines } \\
\text { (EU, 1998) }\end{array}$ \\
\hline $\mathrm{Al}$ & $0.2 \mathrm{mg} / \mathrm{L}$ & & $0.5-0.2 \mathrm{mg} / \mathrm{L}$ & $0.2 \mathrm{mg} / \mathrm{L}$ & $0.2 \mathrm{mg} / \mathrm{L}$ \\
\hline As & $0.05 \mathrm{mg} / \mathrm{L}$ & $0.01 \mathrm{mg} / \mathrm{L}$ & & $0.01 \mathrm{mg} / \mathrm{L}$ & $0.01 \mathrm{mg} / \mathrm{L}$ \\
\hline B & $1.0 \mathrm{mg} / \mathrm{L}$ & & & $4 \mathrm{mg} / \mathrm{L}$ & $1.0 \mathrm{mg} / \mathrm{L}$ \\
\hline $\mathrm{Ba}$ & $1.0 \mathrm{mg} / \mathrm{L}$ & $2 \mathrm{mg} / \mathrm{L}$ & & $2 \mathrm{mg} / \mathrm{L}$ & \\
\hline $\mathrm{Ca}$ & $75 \mathrm{mg} / \mathrm{L}$ & & & & \\
\hline $\mathrm{Cd}$ & $0.005 \mathrm{mg} / \mathrm{L}$ & $0.005 \mathrm{mg} / \mathrm{L}$ & & $0.002 \mathrm{mg} / \mathrm{L}$ & $0.005 \mathrm{mg} / \mathrm{L}$ \\
\hline $\mathrm{Cl}$ & $200 \mathrm{mg} / \mathrm{L}$ & & $250 \mathrm{mg} / \mathrm{L}$ & $250 \mathrm{mg} / \mathrm{L}$ & $250 \mathrm{mg} / \mathrm{L}$ \\
\hline $\mathrm{COD}_{\mathrm{CR}}$ & $15 \mathrm{mg} / \mathrm{L}$ & & & & \\
\hline Hardness & $500 \mathrm{mg} \mathrm{CaCO}_{3} / \mathrm{L}$ & & & $200 \mathrm{mg} / \mathrm{L}$ & \\
\hline $\mathrm{Hg}$ & $0.001 \mathrm{mg} / \mathrm{L}$ & $0.002 \mathrm{mg} / \mathrm{L}$ & & $0.001 \mathrm{mg} / \mathrm{L}$ & $0.001 \mathrm{mg} / \mathrm{L}$ \\
\hline K & $20 \mathrm{mg} / \mathrm{L}$ & & & & \\
\hline $\mathrm{Mg}$ & $30 \mathrm{mg} / \mathrm{L}$ & & & & \\
\hline $\mathrm{Mn}$ & $0.3 \mathrm{mg} / \mathrm{L}$ & & $0.05 \mathrm{mg} / \mathrm{L}$ & $0.5 \mathrm{mg} / \mathrm{L}$ & $0.05 \mathrm{mg} / \mathrm{L}$ \\
\hline $\mathrm{Na}$ & $100 \mathrm{mg} / \mathrm{L}$ & & & $180 \mathrm{mg} / \mathrm{L}$ & $200 \mathrm{mg} / \mathrm{L}$ \\
\hline $\mathrm{Ni}$ & $0.05 \mathrm{mg} / \mathrm{L}$ & & & $0.02 \mathrm{mg} / \mathrm{L}$ & $0.02 \mathrm{mg} / \mathrm{L}$ \\
\hline $\mathrm{Pb}$ & $0.05 \mathrm{mg} / \mathrm{L}$ & $0.015 \mathrm{mg} / \mathrm{L}$ & & $0.01 \mathrm{mg} / \mathrm{L}$ & $0.01 \mathrm{mg} / \mathrm{L}$ \\
\hline $\mathrm{pH}$ & $6.5-8.5$ & $6.5-8.5$ & $6.5-8.5$ & $6.5-8.5$ & $6.5-9.5$ \\
\hline $\mathrm{Se}$ & $0.01 \mathrm{mg} / \mathrm{L}$ & $0.05 \mathrm{mg} / \mathrm{L}$ & & $0.01 \mathrm{mg} / \mathrm{L}$ & $0.01 \mathrm{mg} / \mathrm{L}$ \\
\hline $\mathrm{SO}_{4}$ & $400 \mathrm{mg} / \mathrm{L}$ & & $250 \mathrm{mg} / \mathrm{L}$ & $250 \mathrm{mg} / \mathrm{L}$ & $250 \mathrm{mg} / \mathrm{L}$ \\
\hline TDS & $500 \mathrm{mg} / \mathrm{L}$ & & $500 \mathrm{mg} / \mathrm{L}$ & $600 \mathrm{mg} / \mathrm{L}$ & \\
\hline Turbidity & $5 \mathrm{NTU}$ & & & $5 \mathrm{NTU}$ & \\
\hline $\mathrm{Zn}$ & & & $5 \mathrm{mg} / \mathrm{L}$ & $3 \mathrm{mg} / \mathrm{L}$ & \\
\hline
\end{tabular}




\section{HeAlth Aspects of Used Silicon-BAsed PV MODULES}

This review shows the reasons why PV module roofing needs to be considered as not only a source of energy but a means of harvesting water. Scherba, et al. [100] supported this claim in their work by pointing out that PV assisted green buildings can serve as a source of harvesting quality runoff water due to its ability to eliminate certain pollution like phosphorus and nitrite up to $20 \%$ [92], [101]. This section aimed to collect vital information that have been published for estimating the health implication associated with water consumption without detorting the findings. Since it not easily to get data from PV producer, hence relying on available date is important in studying rainwater collection from PV rooftop. Due to internal industrial policies, it is generally a huge task to collect information from PV manufacturer concerning metal leaching and its effect on human life before and after PV life cycle. The best way to identify metal leaching in harvested water is to review the chemical composition of the rooftop material. Table VIIIa indicates the various chemicals used for different PV technologies. The table summarises the chemical composition involved in the fabrication of eight different PV modules currently available in the market. Table VIIIb focusses only on PV-Nord modules; it appears most of the substance listed are in unprocessed liquid form.

TABLE VIIIA: ChEMICALS AND MATERIALS USED IN THE MANUFACTURING OF PV CELlS [83], [93]-[94], [101]

\begin{tabular}{|c|c|c|c|c|c|c|c|}
\hline $\begin{array}{l}\text { Crystalline } \\
\text { silicon cells }\end{array}$ & $\begin{array}{l}\text { Polycrystalline } \\
\text { Silicon cells }\end{array}$ & $\begin{array}{l}\text { Amorphous } \\
\text { silicon }\end{array}$ & $\begin{array}{l}\text { Cu2S/Cds } \\
\text { cells }\end{array}$ & $\mathrm{CdTe} / \mathrm{CdS}$ & CIGS Cells & CIGS Cells & GaAs Cells \\
\hline Aluminum & Aluminum & Acetone & $\begin{array}{l}\text { Ammonium } \\
\text { chloride }\end{array}$ & $\begin{array}{l}\text { Cadmium } \\
\text { chloride }\end{array}$ & Cadmium & Cadmium & Arsenic \\
\hline Ammonia & Ammonia & Aluminum & $\begin{array}{l}\text { Ammonium } \\
\text { fluoroborate }\end{array}$ & Cadmium & Copper & Copper & Arsenic \\
\hline $\begin{array}{l}\text { Ammonium } \\
\text { fluoride }\end{array}$ & Arsine & Chloro-silanes & $\begin{array}{l}\text { Cadmium } \\
\text { sulfide }\end{array}$ & Molybdenum & Hydride gas & Gallium & Gallium \\
\hline $\begin{array}{l}\text { Hydrochloric } \\
\text { acid }\end{array}$ & $\begin{array}{l}\text { Boron } \\
\text { trichloride }\end{array}$ & Diborane & $\begin{array}{l}\text { Chromate } \\
\text { coating }\end{array}$ & Nickel & $\begin{array}{l}\text { Hydrogen } \\
\text { sulfide }\end{array}$ & Indium & $\begin{array}{l}\text { Hydrochloric } \\
\text { acid }\end{array}$ \\
\hline $\begin{array}{l}\text { Hydrofluoric } \\
\text { acid }\end{array}$ & Copper catalyst & $\begin{array}{l}\text { Germanium } \\
\text { (used in some) }\end{array}$ & Chromate co & & $\begin{array}{l}\text { Hydrogen } \\
\text { selenide }\end{array}$ & Molybdenum & Methane \\
\hline $\begin{array}{l}\text { Isopropyl } \\
\text { alcohol }\end{array}$ & Ethyl acetate & $\begin{array}{l}\text { Hydrochloric } \\
\text { acid }\end{array}$ & $\begin{array}{l}\text { Hydrochloric } \\
\text { acid }\end{array}$ & Tin & Molybdenum & Zinc & Tichloroethlene \\
\hline Nitric acid & $\begin{array}{l}\text { Ethyl vinyl } \\
\text { acetate }\end{array}$ & $\begin{array}{l}\text { Hydrochloric } \\
\text { acid }\end{array}$ & $\begin{array}{l}\text { Hydrochloric } \\
\text { acid }\end{array}$ & & Selenium & & Triethyl gallium \\
\hline Nitrogen & $\begin{array}{l}\text { Hydrochloric } \\
\text { acid }\end{array}$ & Hydrogen & $\begin{array}{l}\text { Hydrogen } \\
\text { sulfide }\end{array}$ & & Zinc & & $\begin{array}{l}\text { Trimethly } \\
\text { gallium }\end{array}$ \\
\hline Oxygen & Hydrogen & Isopropanol & Methanol & & & & \\
\hline Phosphorus & $\begin{array}{l}\text { Hydrogen } \\
\text { fluoride }\end{array}$ & Nitrogen & Nickel & & & & \\
\hline $\begin{array}{l}\text { Phosphorus } \\
\text { oxychloride }\end{array}$ & $\begin{array}{l}\text { Hydrogen } \\
\text { peroxide }\end{array}$ & Phosphine & Nitrogen & & & & \\
\hline Silane & $\begin{array}{l}\text { Ion amine } \\
\text { catalyst }\end{array}$ & Phosphoric acid & $\begin{array}{l}\text { Polyvinyl } \\
\text { butyrol }\end{array}$ & & & & \\
\hline Silver & Nitric acid & $\begin{array}{l}\text { Silicon } \\
\text { tetrafluoride }\end{array}$ & $\begin{array}{l}\text { Sodium } \\
\text { chloride }\end{array}$ & & & & \\
\hline $\begin{array}{l}\text { Sodium } \\
\text { hydroxide }\end{array}$ & Nitrogen & Silicon & $\begin{array}{l}\text { Tantalum } \\
\text { pentoxide }\end{array}$ & & & & \\
\hline Sulfuric acid & Phosphine & $\begin{array}{l}\text { Sodium } \\
\text { hydroxide }\end{array}$ & zinc & & & & \\
\hline Tin & $\begin{array}{l}\text { Phosphorus } \\
\text { trichloride }\end{array}$ & Tin & $\begin{array}{l}\text { Zinc } \\
\text { fluoroborate }\end{array}$ & & & & \\
\hline
\end{tabular}

TABLE VIIIB: EXAMPLE OF ChEMICALS AND MATERIALS USED IN THE MANUFACTURING OF PV-NORD MODULE [63], [93], [101]-[102]

\begin{tabular}{|l|l|}
\hline Silicone & Acrylonitrile-butadiene-styrene copolymer \\
\hline 4,4,7,7-Tetraethoxy-3,8-dioxa-4,7-disiladecan & Tetrabrombisfenol A, 6-15 \\
\hline 3-(2-Aminoethylamino)-propytrimetoxysilan & Antimonoxid, 2-6 \\
\hline 3-Aminopropylyltrieethoxysilan & Brominated epoxioligomer, 4-8 \\
\hline Methanol & Vinyl acetate \\
\hline n-hexan & Copper tin plated \\
\hline Butan-2-on O, O', O"-(methylsidyn)trioxim & Modified Epoxy \\
\hline Oxim silan & EVA \\
\hline 3-(diethoxymethylsily)propylamine & Ethylene vinyl acetate copolymer \\
\hline Polysiliconureaethylester & Stabiliser and addditives \\
\hline Propan-2-ol & 2-propanol \\
\hline Toluene & Carboxylic acids \\
\hline Butanol & Modified resin \\
\hline Isoalcane C7-C10 & Polyvinylfluorid \\
\hline Aluminum & Titanium dioxide \\
\hline Hotmelt adhesive & Modified acrylic dispersion \\
\hline Sand & Silver \\
\hline Soda & Tin \\
\hline Dolomite & CaCO \\
\hline
\end{tabular}

Note: this list provides only general information on PV modules and does not apply to a specific product. 


\section{A. Photovoltaic (PV) Technologies}

Since PV rooftop water harvesting is not as old as conventional rooftop water harvesting, there is growing concern regarding the health impact of the usage of such water. Hence, there is a need to explore the toxicity of PV modules to clarify this gap in the literature. This study will now look at a typical crystalline silicon PV and thin-film PV. The general knowledge is that silicon forms of PV are not toxic and do not pose any health challenges to the user. Silicon-based PV makes up $90 \%$ of the total installed PV worldwide [103]-[106]. In most countries, the vast majority of the PV used are crystalline based modules with $80 \%$ of its content being housed in an aluminium frame and tempered glass front. PV modules are made of two essential components, which can be classified as a major and minor component.

The major component which makes up the active cell is about $5 \%$ silicon. The minor components are essential for the active layer to function effectively. In most cases, the first point to check regarding a PV fault is glass breakage and surface delamination. The silicon cells and lead connectors in the module are the only internal active component of a PV module. In contrast, the external active element is the connecting wire which runs from the cell to the back of the panel. In total, the active conductive component is about $5 \%$ by weight of the PV panel. The understanding of how toxic any element of this $5 \%$ weight can be is an excellent way to answer the question of any health concern of customers. The active part is made of $100 \%$ silicon if the standard refining process is followed. In the refining process boron and phosphorous are added in small quantities, but these elements have little or no toxicity. Another vital component of the PV cell is the thin antireflective coating called the minor component, which usually contains some amount of silicon nitride or titanium dioxide [101], [102]. Though the latter is gradually being left out from most PVs due to its toxic nature it is necessary to talk about it because oldest PVs in residential houses are made of old panels made before the restriction of use of titanium diode. Furthermore, it is vital to know that the minor part contains a tiny amount of lead in some PV cells. Lead is known to be harmful to humans, especially little children, when it exceeds the safety limit. Next are the aluminium layers with silver strip alloy on the front and back sides of the PV cell [103]. Another possible source of lead is the degradation of silica and fluxes that are heated to a high temperature to form glass frit; historically before the refining process, this silica and fluxes contain a small quantity of lead oxide. All the cells in the PV module are connected by solder, which historically contained about $36 \%$ lead.

Traditionally solar cell manufacturers used a tin-based solder containing some amount of lead. However, most PV companies have switched to unleaded solder. Harmful metals such as cadmium are also present in the glass frit or the solder used in the panel. In its evaluation of PV panels, the Silicon Valley Toxics Coalition [104] found that these metals a negligible quantity, so cannot be harmful to humans. However, this study was conducted on modules that were not close to the end of their life span. Hence this conclusion cannot be said to be the same for a degraded PV panel where part of the soldering material has undergone some form of oxidation due to long time exposure therefore is more likely to leach. When leaching occurs, it is possible to have complex formation induced by other reactions. Lead is gradually being phased out in line with the 2015 Solar Scorecard drawn up by the Silicon Valley Toxics Coalition [104]. In 2015 two PV companies were certified to join the initial $12 \mathrm{PV}$ companies in the previous year after meeting the Restriction of Hazardous Substances standard (RoHS) [105]. According to Directive 2011/65/EU RoHS is a globally accepted standard for measuring hazardous substances of products [106]. According to RoHS a PV panel must contain cadmium and lead below the thresholds of 0.01 for Cadmium and less than $0.1 \%$ of lead; the aluminium solder of quantity than exceed $0.1 \%$ of lead in an ideal situation [106]. However, not all PV manufacturer follows these rules because (1) there is no effective system in place to monitor $\mathrm{PV}$ producers and certify that what is wrote is correct. (2) The primary aim of RoHS appears not to be for PV producer hence it does not apply to them as there is no accountability in this regard [107], [108]. This was seen from RoHS directive item no 17 [109], [110].

If the quantity of lead used in PV is so negligible, why be concerned about it? The truth is that this is not much of an issue with PV panels that are not defective. However, there is a concern when the module begins to degrade, so there needs to be more research on this aspect. The average life span of a PV module is 25 years; this is only possible when no destructive defect occurs. The presence of a defect can degrade the lamination of layers, which will expose the internal layer part or minor component to moisture. According to Sinha et al. [111]-[113], breakage and delamination can expose the lead to moisture and enhance leaching to rainwater collected from such a panel [114]. An International Energy Agency Photovoltaic Power study reported that panels are designed to get close to zero leaching at the end of panel lifetime, and the conclusion was there was no danger from leaching again, that result could be different when natural leaching occurs from old, degraded rooftop modules [113], [114].

\section{B. Cadmium Telluride (Cdte)}

The process in which cadmium mixes are utilised as fine particles pose a danger to human health because these fine particles at an advanced stage can attack the lungs. Cadmium (Cd) contaminants can cause a cellular breakdown of the lungs. Its introduction into the body can affect bones and kidneys [112], [114]. Moreover, air-containing cadmium can bring about metal fume fever, pneumonitis, aspiratory edema, and can result in death [115], [116]. Cadmium is formed as a side effect of zinc mining; the degrees of $\mathrm{Cd}$ production depends on the volume of zinc extracted. A considerable amount of $\mathrm{Zn}$ is formed during mining operations, and it is safe to say therefore that reasonable measures of $\mathrm{Cd}$ are produced as a result of $\mathrm{Zn}$ mining. Consequently, the leaching of $\mathrm{Cd}$ from CdTe modules create uncertainty in the quality of rainwater harvest from cadmium telluride (CdTe) based PV panels. Harvested rainwater can help provide quality water needed to improve life, hence ensuring also that 
there is a reduction in health-related risk is paramount in water sustainability. The less toxic nature of $\mathrm{Cd}$ reported by various authors for example Nkuissi et al. [115], [116] is based on the fact that $\mathrm{Cd}$ appears in the form of CdTe which is chemically very stable and insoluble to water. In that capacity, it might be less poisonous when compared to free natural $\mathrm{Cd}$.

Under ambient conditions, CdTe has a zero vapour pressure, therefore it is impossible for CdTe PV modules to emit any vapour when used as a rooftop. The main or the more viable route for $\mathrm{Cd}$ to be emitted and consumed by occupants is if a fire occurs and consumes the modules. Again, this may not be enough to release Cd from CdTe PV modules as residential fires typically have temperatures in the range of $800{ }^{\circ} \mathrm{C}$ to $1000{ }^{\circ} \mathrm{C}$. At a temperature below $1000{ }^{\circ} \mathrm{C}$ $\mathrm{Cd}$ cannot be released since CdTe melts at a temperature of $1041{ }^{\circ} \mathrm{C}$ while $\mathrm{CdS}$ has a melting point of $1750{ }^{\circ} \mathrm{C}$ [116]. According to Patterson et al. [117], Thumm et al. [118], and Steinberger [119], residential fire outbreaks do not emit Cd as the temperature reached is below Cd melting point and as such, the vaporisation energy is not released. The potential for CdTe discharges could occur on account of hotter fires or can occur from burning spent PV modules. In the first case, the fire itself presumably would cause a lot more severe hazard than any potential Cd outflows [120]. In the second case this can happen if $\mathrm{CdTe}$ modules end in refuse burning streams [121]-[125].

\section{SElECted Findings RElEVAnt To PV RoOFTOP}

In 2011, Gottesfeld et al. [126] reported on lead batteries utilised in existing PV frameworks in China and India. The authors assessed natural lead emanations in China and India from modern units introduced in terms of their solar energy goals. They stated that there was a plan to increase PV systems in China and India, and this could account for 386 KT and $2030 \mathrm{KT}$ of environmental lead loss, respectively. The increase in PV systems consumed $1 / 3$ of universally produce lead in 2019 as reported. They suggested that the producer should invest in a naturally controlled process during lead purifying, battery fabricating, and reusing [126], [127]. The control plan should investigate and manage the entire natural release of lead in the industry. This could be a problem when the natural outflow of lead is absorbed and washed down by rainwater from the roof, thereby contaminating the harvested water.

The benefit of integrated sustainable PV assisted itemised green roofs include: i) the increase of roof temperature because of building integrated electrical thermal power generation; ii) polluted rainwater runoff can be cleaned via a green roof [127]. Though the primary aim of the roof is to provide protection and cover from atmospheric conditions, a green roof integrated with PV has the benefit of many other functions, and can contribute to the reduction of global environmental problems. The function of a roof in the current era has changed from a mere protective covering from weather to a platform accommodating property building technologies such as extensive or intensive roof, rainwater harvester and solar energy collector. In order to prove beyond doubt the safety and quality of water harvested from such a roof, long-term assessment is needed. Long-term assessment will help to see the changes that are not just temporary and will help to validate the accuracy of existing data. In conclusion, BiPVT, green roof and rainwater harvesting system can be combined to enjoy multiple advantages.

The PV cell production process is associated with a certain degree of hazardous chemical and physical substances depending on the production techniques. These hazardous substances include $\mathrm{x}-\mathrm{Si}$, acid burns, $\mathrm{SiH} 4$ explosions, $\mathrm{Pb}$ solder, Cd toxicity in the case of CdTe, carcinogenicity, As carcinogenicity, $\mathrm{H}_{2}$ flammability. In the crystalline silicon PV modules, the visible possible health issues are chemical burns, nitric and alkali fume inhalation. The chemicals are used for removing dopant oxides and cleaning reactors, according to Fthenakis [128]. It is safe to say that when these PV modules are used as rooftop material, there is a possibility of certain metal leaching immediately after deployment or at the end of their life span. Also possible is the harvesting of contaminated rainwater during the first stage of deployment; this can happen when the chemicals used for cleaning are not removed adequately from the module surface. Again, soldering material like lead can be a problem at this stage. Fthenakis [128] concluded by saying that some materials used by photovoltaic modules producers have health and safety concerns if standard precaution is not observed.

Kannan et al. [129] ascertained that the leaching of metals from PV modules is unlikely because of the protective nature of PV panels. Therefore, the fear of toxic metals like $\mathrm{Pb}$ and Cd being released by a PV module should not be a concern, except when a PV module has reached its life span and is disposed of, and $\mathrm{Pb}$ and $\mathrm{Cd}$ could leach into ground runoff water. The concern for contamination of $\mathrm{Pb}$ and $\mathrm{Cd}$ is because such leaching can find its way into the water body. Kannan et al. [129] also tested Se contamination the PV systems, and the highest concentration recorded was close to the conservative risk thresholds established by the EPA's [130]. This is worrisome because the concentration of Se can be a potential risk to plants and animals. This result cannot be said to be the same for an indirect assessment of Se concentration around PV systems. Also, essential to note is that perovskite solar cell behave differently to crystalline solar cell modules. One example is the recent introduction of $\mathrm{Sr}$ to boost the efficiency of perovskite solar cells; the toxicity needs to be studied.

Understanding the chemical composition of PV modules is key to studying its toxicity when employed as a house roofing material. Nkuissi et al. [116] and Ramos-Ruiz et al. [131] conducted separate study on the overview of the toxicity of materials used in photovoltaic industries. The importance of this is that it gives an idea of what metal contaminant one is likely to find in harvested water in the case of leaching [132], [133]. Over the years PV production has improved with the emergence of new materials. However, this can also lead to an increase in health risks associated with PV usage. For example, wafer-based PV is known to be less toxic compared to third-generation PV, which are nanomaterial-based PVs, and perovskite solar cells. Some studies found there is variability in the use of chemicals for the fabrication of similar types of PV modules depending on the manufacturers. It is essential to analysis differences in data based on PV 
technology and producers, but unfortunately most results out there seem not to account for this fundamental concern [132], [133]. There are materials which are toxic especially during the production stage which have no immediate effect on rainwater harvested from PVs except at the early stage due to improper clean of the module before taken out of the factory. The summary of the potential health and environmental concern of using PV panels like CdTe, a-Si and c-Si has been present in Tables I to V. Nkuissi et al [116] specifically pointed to CdTe, CdS, and cadmium chloride as the most hazardous chemical materials used in thin-film PV module manufacturing.

Having seen the potential advantages of a green roof, building technology has started rolling out the integrated sustainable green roof to have a single system that can provide a rainwater harvested system (RWHS), energy generation and amelioration of the greenhouse effect for environmental benefits. Previously three forms of green roofs were listed, namely, intensive green roof, semi-intensive green roof, and an extensive green roof, unlike the previous authors who focused on only intensive and extensive green roof types [127], [133]. Preeti Nain et al. [134] collaborated Li and Yeung [127] by showing the need to balance research on an intensive green roof, which is seen as challenging due to technical expertise. It is only by focusing future research on this non-flexible green roof type that advancement in the integrated green roofs will emanate. A green roof also helps to regulate house warming with much more advantage than a white-painted roof. Judging from available environmental data, one can conclude that green roofs are best for urban regions. Concerning water collection quality, that study did not deal with non-PV assisted rooftops. However, it is true to say that green roofs can be a source of gas pollution which can contaminate rainwater collection, an example being phosphorus release. This is possible because of its thermal performance; hence, more study is required in this since the six roofs studied in their work performed differently.

Literature shows that the quality of harvested rainwater can be affected by the nature of the material used for roofing [114], [134]. This motived to work on the effect of solar modules as rooftop catchment to determine the health risks consumers face. The importance of PV rooftop as a solution to the current sporadic power supply in most provinces of some developing nations, and being able to harvest water from it was the reason for the study. Qiao et al. [135] harvested rainwater from PV rooftops by merely collecting the runoff from installed solar panels which showed some level of change in the water quality. The rainwater was stimulated from 23 syringes to produce synthetic rainwater drips [135]. This provided the opportunity to characterise the initial quality of the water so that is can be compared with quality after runoff. The analysis was done after 24 hours to ensure no significant contamination from storage tanks. If such a technique was not available, the other way to do this experiment would be to do air rainwater collection and compare this with runoff water from a PV roof. In both cases, certain percussion has to be taken, and the results are presented in Table VI. It is recognised that the quality indicators of harvested rainwater in PV rooftop could change once the modules begin to degrade. Results show that synthetic rainwater has better quality than EPA drinking water standards except in the case of nitrate, which was above the limit with $30 \mathrm{mg} / \mathrm{L}$. At the same time, it was lower than the harvested water from new Si thin-film modules. All the values for the harvested water seem to be higher than synthetic rainwater and lower than EPA [123], [135] values except for turbidity (NTU) and Nitrate (nm-N/L). However, regarding metal leaching, Qiao et al. [135] found that both the rainwater and synthetic rainwater collected from runoff of PV modules were below the recommended values,

Eberspacher et al. [136] study was tailored in line with public health and safety concerns of a PV project on a large scale. Cadmium telluride solar cells stood out as the one flashing red light due to its $\mathrm{Cd}$ content, which is known to be toxic. Cadmium telluride solar cells are emerging PV cell technology with much potential to compete with crystalline silicon solar cells. However, more study is needed to have sufficient data that can stand the test of time about the degree of its toxicity. Eberspacher et al. [136] reported that CdTe was the most popular thin-film PV deplored in North Carolina, back in 2016. The study indicated that its negative and safety effect is inconsequential, while its public health advantages are much higher than its adverse effects. More companies are being certified by the day to make sure that specific health risks are not compromised. So far, fourteen companies had already registered with Silicon Valley Toxics Coalition to put their operation under check by this regulating body [107], [137]. Overall CdTe passed the EPA's Toxic Characteristic Leaching Procedure test like silicon solar modules.

Ramos-Ruiz et al. [137] observed the need to arrange water research in complex biogeochemical conditions since more work had been about the chemical dissolution of $\mathrm{Cd}$ and Te from CdTe solar. Most of these works were on simulation of a landfill and outdoor environment. The study focused on biogeochemical issues common in municipal MSW landfills and analysis of the possibility of contaminants entering the water body. Such indiscriminate disposal of PV material can migrate to the water body which, when fetch for consumption, can be of health concern to consumers. Also, a released metal such as $\mathrm{Cd}$ can vaporise and mix with air, which can be captured by rainwater. Alternatively, such vaporised $\mathrm{Cd}$ can deposit on a rooftop and later mix with runoff water. The authors recommended that landfills should be designed in an area far from water bodies, farms or homes due to leaching potential and ability to influence the $\mathrm{PH}$ value of surrounding land.

The hazardous nature of PV panels has always been a concern; the quest to eliminate any possible risk started a long time ago. On the other hand, the expectation was always to produce PV technologies that will help to lower the environmental impacts of PV systems. Other studies have compared the negative impact of a PV system to pollution or emissions in Europe [132], [137]. The comparison was restricted to global warming, acidification and energy, and it proved that PV performed better. At the same time, the new PV modules produced are proving to have less environmental effects compared to the old PVs in the market [137].

Vital knowledge of possible metal release from PV modules at the end of life span is essential in the 
understanding of potential chemical substance release from PV rooftop. In most cases, life span may not be directly proportionate, but it gives a pointer of what to expect. From Nain et al. work's it was clear that environmental factors like high UV irradiation, humidity, and temperature accelerate the deterioration process of PV solar modules [134], [137]. This act of deterioration is called degradation and can upset the components of the PV module. If the modules remain exposed to these environmental factors, these factors will alter the physical features of the modules. This is the leading cause of defect or damages, such as delamination, discolouration, and corrosion in PV modules; if care is not taken, it will result in a non-functional module in a worst-case scenario. This is the primary reason why there exists uncertainty in the health and safety issues for PV rooftops. The situation is even more worrisome for thin-film based PV compared to silicon-based PV. PV waste management is still a new field of research and the absence of a functional standard management system is a challenge to a safe recycling process. Indiscriminate dumping of modules can complicate underground water quality due to toxic leaching of specific metals from dumped PV modules after a certain period.

Reynolds et al. [137] researched the risk associated with thin-film PV with a focus on CdTe thin-film photovoltaic modules. The first environmental challenge with $\mathrm{CdTe}$ is the release of a negligible amount of $\mathrm{Cd}$ into the surrounding area due to its electrodeposition processes during the production stage. In fabrication of CdTe PV modules, there must very clean working conditions under strict industrial control. As pointed out by Reynolds et al. [137], Cd is not only released during production but also during decommissioning and from damage. Lastly extracting $\mathrm{Cd}$ during recycling is a challenge because of its small quantity; therefore, the effort can be discouraging [138], [139].

\section{CONCLUSION}

The finding review here can be classified under two heading, which is rooftop runoff fine convention roof and PV roof runoff. Multiple sources of contamination can originate from the roof. Authors have a range of views about this, as is evident from the variety of results reported. These variations are due to the type of material used for the roofing, storage material and duration of storage, roof and storage tank maintenance, age of roofing material, environmental factors, and climatic factors. The concentration of metallic leaching found in roof-harvested water is believed to be directly proportional to the age of the roofing material. In the case of $\mathrm{PV}$, it is essential to note that the quality of harvest of rainwater from PV modules also depends on i) type of photovoltaic panel used ii) the state of the PV modules iii) the age of the PV modules. The kind and degree of pollutant rainwater acquired from the roof changes with the season, ambient temperature, age of the complete roofing system. This is obvious from the results presented in this paper.

\section{CONFLICT OF INTEREST}

The authors declare no conflict of interest.

\section{AUTHOR CONTRIBUTIONS}

All authors had contributed to the study and approved the manuscript.

\section{ACKNOWLEDGMENT}

The authors wish to thank Cape Peninsula University of Technology, South Africa for the postdoctoral fellowship funding.

\section{REFERENCES}

[1] N. Mason, "Industry developments that sustain the growth of crystalline silicon PV output," in Proc. the Photovoltaic Science, Applications, and Technology Conference, Durham, UK, March, pp. 28-30, 2007.

[2] P. D. Moskowitz and V. M. Fthenakis, "Environmental, health and safety issues associated with the manufacture and use of II-VI photovoltaic devices," Solar Cells, vol. 30, issues 1-4, pp. 89-99, 1991.

[3] P. D. Moskowitz, "An overview of environmental, health and safety issues in the photovoltaic industry," Solar Cells and Their Applications, New York, NY: John Wiley \& Sons, Inc., pp. 391-416, chapter 18, 1995.

[4] H. Bravo et al., "Acid rain in Mexico case: Maya monuments," Air Pollution, Boston, Southampton, 1997.

[5] M. M. Hand, S. Baldwin, E. DeMeo, J. M. Reilly, T. Mai, D. Arent, G Porro, M. D. Meshek, and Sandor, "National renewable energy laboratory (NREL). Renewable electricity futures study," Golden, CO: National Renewable Energy Laboratory, 2012.

[6] A. Campisano, D. Butler, S. Ward, M. J. Burns, E. Friedler, K. Debusk, L. N. Fisher-Jeffes, E. Ghisi, A. Rahnman, H. Furumai et al., "Urban rainwater harvesting systems: Research, implementation and future perspectives," Water Res., vol. 115, pp. 195-209, 2017.

[7] A. Teston, M. S. Geraldi, B. M. Colasio, and E. Ghisi, "Rainwater harvesting in buildings in Brazil," A Literature Review. Water, vol. 10, p. 471, 2018.

[8] C. Eberspacher, V. M. Fthenakis, and P. D. Moskowitz, "Environmental, health and safety issues related to commercializing CuInSe2-based photovoltaics," BNL-63334, Brookhaven National Laboratory, Upton, New York, 1994.

[9] E. Nieuwlaar and E. Alsema, "Environmental aspects of PV power systems," IEA PVPS Task 1 Workshop, Report No. 97072, Utrecht University, The Netherlands, 1997.

[10] O. Edenhofer, R. Pichs-Madruga, Y. Sokona, K. Seyboth, P. Matschoss, S. Kadner, T. Zwickel, P. Eickemeier, G. Hansen, S. Schlömer, and C. Stechow, "IPCC special report on renewable energy sources and climate change mitigation," Working Group III of the Intergovernmental Panel on Climate Change, Cambridge University Press, Cambridge, United Kingdom and New York, NY, USA, 2011.

[11] B. D. Wood and J. Muhs, "Adaptive full-spectrum solar energy systems," NETL Report No. 41164R02, 2002.

[12] G. O. Osayemwenre and E. L, Meyer, "Confirmation of the Degradation of Single Junction Amorphous Silicon Modules (a-Si:H), International Journal of Photoenergy, Article ID 3452180, p. 13, 2019.

[13] Union of Concerned Scientists Scientists. Environmental Impacts of Solar Power. [Online]. Available: https://www.ucsusa.org/clean_energy/our-energy-choices/renewable-e nergy/environmental-impacts-solar-power

[14] Environmental Protection Agency (EPA), "Guidelines for water reuse," Washington, DC, 2004.

[15] C. B. Mendez, J. B. Klenzendorf, B. R. Afshara, M. T. Simmons, M. E Barrett, K. A. Kinney, and M. J. Kirisits. "The effect of roofing material on the quality of harvested rainwater," Water Research, vol. 45, no. 5, pp. 2049-2059, 2011.

[16] B. Ozarisoy, "Reviewing Green roof design approaches: Case study of residential buildings" Thesis submitted to the Institute of Graduate Studies and Research in partial fulfillment of the requirements for the Degree of Master in Architecture, Eastern Mediterranean University, 2013.

[17] J. Baron and A. S. Denning, "The influence of mountain meteorology on precipitation chemistry at low and high elevations of the Colorado front range USA," Atmos. Environ., pp. 2337-2349, 1993.

[18] D. Drysdale, An Introduction to Fire Dynamics, New York, NY: Wiley, p. $424,1985$.

[19] J. Johnston, "Newton Building Green: A guide using plants on roofs, Walls and Pavements," London Ecology Unit, 1995. 
[20] N. H. Wong et al. "The effects of rooftop garden on energy consumption of a commercial building in Singapore," Energy and Buildings, vol. 35, pp. 353-364, 2003.

[21] S. W, Peck, C. Callaghan, M. E. Kuhn, and B. Bass, "Greenbacks from green roofs: Forging a new industry in Canada," Status Report on Benefits, Barriers and Opportunities, 1999.

[22] B, Krupka, Dachbegr ünung. Pflanzen-undVegetationsanwendung an Bauwerken, Stuttgart: Ulmer, 1992.

[23] W. Kolb and T. Schwarz, "Dachbegr unung, intensiv und extensive," Stuttgart: Ulmer, 1999.

[24] S. Cook, "Rainwater harvesting in Gansu Province, China: Development and modernity in a sate sponsored rural water supply project," Doctor of Philosophy Dissertation, Yale University, 2004.

[25] Environmental Protection Agency (EPA), "Guidelines for water reuse," EPA/625/R-04/108, 2004, Washington, DC.: EPA.

[26] IBM. (2007). IBM Pioneers Process to Turn Waste into Solar Energy. [Online]. http://www-03.ibm.com/press/us/en/pressrelease/22504.wss

[27] L. X. Sheng, T. S. Mari, A. R. M. Ariffin, and H. Hussein, "Integrated sustainable roof design," in Proc. 2011 International Conference on Green Buildings and Sustainable Cities, vol. 21, pp. 846-852, 2011.

[28] J. B. Belden, C. S. Hofelt, and M. J. Lydy, "Analysis of multiple pesticides in urban storm water using solid-phase extraction," Arch. Environ. Contamin. Toxicol., vol. 38, pp. 7-10, 2000.

[29] M. T. Bomboi and A. Hernandez, "Hydrocarbons in urban runoff: Their contribution to the wastewaters," Water Res., vol. 25, pp. $557-565,1991$.

[30] K. Levsen, S. Behnert, M. Svoboda, H. D. Winkeler, and J. Zietlow, "Organic compounds in precipitation," Chemosphere, vol. 21, pp. 1037-1061, 1990.

[31] R. Farreny, T. Morales-Pinzón, A. Guisasola, C. Tayàd, J. Rieradevall, and X. Gabarrell, "Roof selection for rainwater harvesting: Quantity and quality assessments in Spain," Water Research, vol. 45, 2011, 10.1016/j.watres.2011.03.036, 3245-3254.

[32] T. D. Bucheli, F. C Grubler, S. R. Muller, and R. Schwarzenbach, "Simultaneous determination of neutral and acidic pesticides in natural waters at the low nanogram per liter level," Anal. Chem., vol. 69, pp. 1569-1576, 1997.

[33] T. D. Bucheli, S. R. Muller, S. Heberle, and R. P. Schwarzenbach, "Occurrence and behavior of pesticides in rainwater, roof runoff, and artificial stormwater infiltration," Environ. Sci. Technol., vol. 32, pp. 3457-3464, 1998.

[34] T. D. Bucheli, S. R. Muller, A. Voegelin, and R. P. Schwarzenbach, "Bituminous roof sealing membranes as major sources of the herbicide (R,S)-mecoprop in roof runoff waters: potential contamination of groundwater and surface waters," Environ. Sci. Technol., vol. 32, pp. 3465-3471, 1998.

[35] M. M. Nakajima and F. H. Furumai, "Modeling of runoff behavior of particulate-bound polycyclic aromatic hydrocarbons (PAHs) from roads and roofs," Water Res., vol. 38, pp.4475-4483, 2004.

[36] J. Johnston, "Newton building green: A guide using plants on roofs, walls and pavements," London Ecology Unit, 1995.

[37] C. N. Hewitt and M. B. Rashed, "Removal rates of selected pollutants in the runoff waters from a major rural highway," Water Res., vol. 26, pp. 311-319, 1992

[38] T. Hvitved-Jacobsen, N. B. Johansens, and Y. A. Yousef, "Treatment systems for urban and highway runoff in Denmark," Sci. Total Environ., vol. 146/147, pp. 499-506, 1994.

[39] P. S. Mikkelsen, M. Häfliger, M. Ochs, J. C Tjell, P. Jacobsen, and M. Boller, "Experimental assessment of soil and groundwater contamination from two old infiltration systems for road runoff in Switzerland," Sci. Total Environ., vol. 189/190, pp. 341-347, 1996.

[40] N. R. Thomson, E. A. Mcbean, W. Snodgrass, and B. Manstrenko, "Highway stormwater runoff quality: development of surrogate parameter relationships," Water Air Soil Pollut., vol. 94, pp. 307-347, 1997.

[41] R. A. Relyea "A cocktail of contaminants: How mixtures of pesticides at low concentrations affect aquatic communities," Oecologia, vol. 159 pp. 363-376.

[42] Z. Polkowska, T. Gorecki, and J. Namiesnik, "Quality of roof runoff waters from an urban region (Gdansk, Poland)," Chemosphere, vol. 49, pp. 1275-1283, 2002.

[43] M. F Hovmand and J. Bille-Hansen, "Atmospheric input to Danish spruce forests and effects on soil acidification and forest growth based on 12 years measurements," Water Air Soil Pollut., vol. 116, pp. 75-88, 1999.
[44] C. Bini and F. Bresolin, "Soil acidification by acid rain in forest ecosystems: A case study in northern Italy," Sci. Total Environ., vol. 222, pp. 1-15, 1998.

[45] C. Leonardo, "A review of the relevance of demography to australian water planning," Journal of Population Research, vol. 25, no. 2, 2008 , pp. 119-139.

[46] G. Raben, H. Andreae, and M. Meyer-Heisig, "Longterm acid load and its consequences in forest ecosystems of Saxony (Germany)," Water Air Soil Pollut., vol. 122, pp. 93-103, 2000.

[47] World Health Organization (WHO), Guideline for Drinking Water Quality, World Health Organization: Geneva, Switzerland, 2004.

[48] Z. Polkowska, M. Grynkiewicz, A. Przyjazny, and J. Namiesnik, "Determination of concentrations of some components in precipitation over nonindustrialized regions in the vicinity of Gdansk," Pol. $J$ Environ. Stud., vol. 8, pp. 425-431, 1999.

[49] M. M. Hand, S. Baldwin, E. DeMeo, J. M. Reilly, T. Mai, D. Arent, G. Porro, M. Meshek, and D. Sandor, "National renewable energy laboratory (NREL)," Renewable Electricity Futures Study, Golden, CO: National Renewable Energy Laboratory, 2012.

[50] O. Edenhofer, M. Kowarsch, "Cartography of pathways: A new model for environmental policy assessments," Environmental Science and Policy, vol. 51, pp. 56-64, 2015.

[51] K. Hamilton, B. Reyneke, M. Waso et al., "A global review of the microbiological quality and potential health risks associated with roof-harvested rainwater tanks," Clean Water, vol. 2, p. 7, 2019.

[52] Environmental Protection Agency (EPA), "Guidelines for water reuse," EPA/625/R-04/108, Washington, DC.: EPA, 2004.

[53] IBM. (2007). IBM Pioneers Process to Turn Waste into Solar Energy. [Online]. Available: http://www-03.ibm.com/press/us/en/pressrelease/22504.wss

[54] Z. Polkowska, "Quality of road and roof runoff waters from an urban region with Gdańsk (Poland) as an example," presented at 1st WSEAS International Conference on ENVIRONMENTAL and GEOLOGICAL SCIENCE and ENGINEERING (EG'08) Malta, September 11-13, 2008.

[55] M. Grynkiewicz, Z. Polkowska, T. Górecki, and J. Namieśnik, "Pesticides in precipitation from an urban region (Gdansk-Sopot-Gdynia Tricity, Poland) between 1998 and 2000," Water, Air, and Soil Pollut., vol. 149, pp. 3-16, 2003.

[56] J. A. M. H. Hofman and M. Paalman, "Rainwater harvesting, a sustainable solution for urban climate adaptation, Nieuwegein," The Netherlands: KWR Watercycle Research Institute, 2014.

[57] T. Abbasi and S. A. Abbasi, "Sources of pollution in rooftop rainwater harvesting systems and their control," Critical Reviews in Environmental Science and Technology, vol. 41, no. 23, 2011, pp. 2097-2167.

[58] R. Hofman-Caris, C. Bertelkamp, L. Waal, T. Brand, J. Hofman, R. Aa, and J. P. Hoek, "Rainwater harvesting for drinking water production: A sustainable and cost-effective solution in The Netherlands," Water, vol 11, p. $511,2019$.

[59] G. Sammut, E. Sinagra, R. Helmus, and P. Voogt, "Perfluoroalkyl substances in the Maltese environment (I) surface water and rain water," Sci. Total Environ., vol. 589, pp. 182-190, 2017.

[60] World Health Organization, Regulation on the Quality of Water Intended for Human Consumption, Regulation of the Polish Minister of Health, Panthera Design: Tappernøje, Denmark: 2017/2294, 2017.

[61] A. K. Marinoski and E. Ghisi, "Aproveitamento de Água Pluvial Para Usos Não Potáveis em Instituição de Ensino: Estudo de Caso em Florianópolis-SC," Rainwater Harvesting for Non-Potable Uses in Schools: A Case Study in Florianópolis-SC, Ambiente Cosntruído, vol. 8, pp. 67-84, 2008.

[62] E. Ghisi, "Parameters influencing the sizing of rainwater tanks," Water Resour. Manag., vol. 24, pp. 2381-2403, 2010.

[63] Drinkwaterbesluit Besluit van 23 mei. (2011). Houdende bepalingen inzake de productie en distributie van drinkwater en de organisatie van de openbaredrinkwatervoorziening. [Online]. Available: http://wetten.overheid.nl/BWBR0030111/geldigheidsdatum_03-07-20 13

[64] J. Dean and P. R. Hunter, "Risk of gastrointestinal illness associated with the consumption of rainwater, a systematic review," Environmental Science \& Technology, vol. 46, pp. 2501-2507, 2012, $10.1021 / \mathrm{es} 203351 \mathrm{n}$

[65] D. Laia, H. Han, and S. David, "Rainwater harvesting for human consumption and livelihood improvement in rural Nepal Benefits and risks," Water and Environment Journal, vol. 26, 2012 , 10.1111/j.1747-6593.2011.00305.

[66] V. Gomez-Alvarez, R. P. Revetta, and J. W. S. Domingo, "Metagenomic analyses of drinking water receiving different 
disinfection treatments," Applied and Environmental Microbiology, pp 6095-6102, 2012.

[67] W. J. Rhoads, A. Pruden, and M. A. Edwards, "Survey of green building water systems reveals elevated water age and water quality concerns," Environ. Sci., vol. 2, pp. 164-173, 2016.

[68] B. Gouvello, N. Nguyen-Deroche, F. Lucas, and M. C. Gromaire, "A methodological strategy to analyze and improve the French rainwater harvesting regulation in relation to quality," Water Science and Technology, vol. 67, no. 5, pp. 1043-1050, 2013.

[69] Rainwater. [Online]. Available: https://www.who.int/water_sanitation_health/gdwqrevision/rainwater. pdf

[70] C. Vialle, C. Sablayrolles, M. Lovera, M. C. Huau, S. Jacob, and M. Montrejaud-Vignoles, "Water quality monitoring and hydraulic evaluation of a household roof runoff harvesting system in France," Water Resources Management, vol. 26, no. 8, pp. 2233-2241, 2012.

[71] A. Schriewer, H. Horn, and B. Helmreich, "Time focused measurements of roof runoff quality," Corros. Sci., vol. 50, pp. 384-391, 2008.

[72] E. L. Brodie et al. "Urban aerosols harbor diverse and dynamic bacterial populations," in Proc. Natl Acad. Sci., USA, vol. 104, pp. 299-304, 2007.

[73] M. Sterren, A. Rahman, and G. R. Dennis, "Quality and quantity monitoring of five rainwater tanks in Western Sydney," Australia. Journal of Environmental Engineering (United States), vol. 139, no. 3 , pp. 332-340, 2013.

[74] C. A. Evans, P. J. Coombes, and R. H. Dunstan, "Wind, rain and bacteria: the effect of weather on the microbial composition of roof-harvested rainwater," Water Res., vol. 40, pp. 37-44, 2006.

[75] T. Amin and M. Y. Han, "Microbial quality variation within a rainwater storage tank and effects of first flush in Rainwater Harvesting (RWH) System," Australian Journal of Basic and Applied Sciences, vol. 5, no. 9, pp. 1804-1813, 2011.

[76] J. Y. Lee, G. Bak, and M. Han, "Quality of roof-harvested rainwater Comparison of different roofing materials," Environmental Pollution, vol. 162, pp. 422-429, 2012.

[77] G. D. Gikas and V. A. Tsihrintzis, "Assessment of water quality of first-flush roof runoff and harvested rainwater," Journal of Hydrology, vol. 466-467, pp. 115-126, 2012

[78] S. O'Hogain, L. McCarton, N. McIntyre, J. Pender, and A. Reid, "Physicochemical and microbiological quality for water from a pilot domestic rainwater harvesting facility in Ireland," Water and Environment Journal, vol. 25, pp. 489-494, 2011.

[79] S. Ward, F. A. Memon, and D. Butler, "Harvested rainwater quality: The importance of appropriate design," Water Science and Technology, vol. 61, no. 7, pp. 1707-1714, 2010

[80] R. Villar-Navascués, A. Pérez-Morales, and S. Gil-Guirado, "Assessment of rainwater harvesting potential from roof catchments through clustering analysis," Water, vol. 12, p. 2623, 2000, https://doi.org/10.3390/w12092623.

[81] C. B. Mendez, J. B. Klenzendorf, B. R. Afshar, M. T. Simmons, M. E. Barrett, K. A. Kinney, and M. J. Kirisits, "The effect of roofing material on the quality of harvested rainwater," Water Research, vol. 45, no. 5, pp. 2049-2059, 2011.

[82] S. M. Hamdan, "A literature based study of stormwater harvesting as a new water resource," Wat. Sci. Tech. vol. 60, no. 5, pp. 1327-1339, 2009

[83] M. García-Montoya, A. Bocanegra-Martínez, F. Nápoles-Rivera, M. Serna-González, J. M. Ponce-Ortega, and M. M. El-Halwagi, "Simultaneous design of water reusing and rainwater harvesting systems in a residential complex," Comput. Chem. Eng., vol. 76, pp. 104-116, 2015.

[84] J. F. Velasco-Muñoz, J. A. Aznar-Sánchez, A. Batlles-delaFuente, and M. D. Fidelibus, "Rainwater harvesting for agricultural irrigation: An analysis of global research," Water, vol. 11, p. 1320, 2019.

[85] A. Stec and M. Zele `náková, "An Analysis of the E ectiveness of two rainwater harvesting systems located in Central Eastern Europe," Water, vol. 11, p. 458, 2019.

[86] M. I. H. Yaziz, N. Gunting, N. Sapari, and A. W. Ghazali, "Variations in rainwater quality from roof catchments," Wat. Res., vol. 23, no. 6, pp 761-765, 1989

[87] P. Melidis, C. S. Akratos, V. A. Tsihrintzis, and E. Trikilidou, "Characterization of rain and roof drainage water quality in Xanthi, Greece," Environ. Monit. Assess, vol. 124, pp. 15-27, 2007.

[88] M. Chang and C. M. Crowley, "Preliminary observations on water quality of storm runoff from four selected residential roofs," Water Resour. Bull, vol. 29, no. 5, pp. 777-782, 1993.
[89] J. Y. Lee, J.-S. Yang, M. Han, and J. Choi, "Comparison of the microbiological and chemical characterization of harvested rainwater and reservoir water as alternative water resources," Sci. Total Environ., vol. 408, pp. 896-905, 2010

[90] K. DeBusk and W. Hunt, "Rainwater harvesting: A comprehensive review of literature," Water Resources Research Institute of the University of North Carolina (UNC-WRRI-425), 2014.

[91] I. F. Adeniyi and I. O. Olabanji, "The physico-chemical and bacteriological quality of rainwater collected over different roofing materials in Ile-Ife, southwestern Nigeria," Chem. Ecol., vol. 21, no. 3 , pp. 149-166, 2005

[92] A. Avila and M. Alarcon, "Relationship between precipitation chemistry and meteorological situations at a rural site in NE Spain," Atm. Environ., vol. 33, no. 11, pp. 1663-1677, 1999.

[93] M. Chang, M. W. McBroom, and R. S. Beasley, "Roofing as a source of nonpoint water pollution," J. Environ. Manage., vol. 73, pp. 307-315, 2004.

[94] J. He, R. Balasubramanian, D. F. Burger, K. Hicks, J. C. I. Kuylenstierna, and S. Palani, "Dry and wet atmospheric deposition of nitrogen and phosphorus in Singapore," Atmos. Environ., vol. 45, pp. 2760-2768, 2011.

[95] J, Sonne, "Evaluating green roof energy performance," ASHRAE Journal, vol. 48, pp. 59-61, 2006.

[96] A. Demirak, A. Balci, H. Karaoğlu, and B. Tosmur, "Chemical characteristic of rain water at an urban site of south western Turkey,' Environ. Monit. Assess, vol. 123, no. 1-3, pp. 271-283, 2006.

[97] S. Schuler, S. Nishiwaki, M. Dziedzina, R. Klenk, S. Siebentritt, and M. C Lux-Steiner, "Solar cells based on PVD grown CuGaSe2 absorber and device properties," Mater. Res. Soc. Symp. Proc, Warrendale, PA, USA 668, H5.14.1-6, 2001.

[98] C. Hontoria, A. Saa, J. Almorox, L. Cuadra, A. Sanchez, and J. M. Gasco, "The chemical composition of precipitation in Madrid," Water Air Soil Poll., vol. 146, pp. 35-54, 2003.

[99] A. L. Lazrus, E. Lorange, and J. P. Lodge, "Lead and other metal ions in the United States precipitation," Environ. Sci. Tech., vol. 4, pp. 55-58, 1970.

[100]A. Scherba, D. J. Sailor, T. N. Rosenstiel, and C. C. Wamser, "Modeling impacts of roof reflectivity, integrated photovoltaic panels and green roof systems on sensible heat flux into the urban environment," Building and Environment, vol. 46, no. 12, pp. 2542-2551, 2011, ISSN 0360-1323.

[101]F. D. Butler, "Simulating the performance of rainwater collection and reuse systems using behavioural models," Building Services Engineering Research and Technology. vol. 21, no. 2, pp. 99-106, 2000.

[102]A. Scherba and D. J. Sailor, "Integrated photovoltaic panels and green roof systems on sensible heat flux into the urban environment," Building and Environment, vol. 46, no. 12, pp. 2542-2551, 2010, ISSN 0360-1323.

[103]T. D. Bucheli, S. R. Muller, S. Heberle, and R. P. Schwarzenbach, "Occurrence and behavior of pesticides in rainwater, roof runoff, and artificial stormwater infiltration," Environ. Sci. Technol., vol. 32, pp. 3457-3464, 1998.

[104]Silicon Valley Toxics Coalition. (2015). Solar Scorecard. [Online]. Available: www.solarscorecard.com/2015/2015-SVTC-Solar-Scorecard.pdf

[105]European Commission. Recast of Reduction of Hazardous Substances (RoHS) Directive. [Online]. Available: http://ec.europa.eu/environment/waste/rohseee/index en.htm

[106]European Union. (2011). Directive 2011/65/EU of the European parliament and of the council of 8 June 2011 on the restriction of the use of certain hazardous substances in electrical and electronic equipment. Official Journal of the European Union. [Online]. Available: http://data.europa.eu/eli/dir/2011/65/oj

[107]European Commission. (2011). Study on Photovoltaic Panels Supplementing the Impact Assessment for a Recast of the Weee Directive. [Online]. Available: http://ec.europa.eu/environment/waste/weee/pdf/Study\%20on\%20PVs $\% 20$ Bio\%20final.pdf

[108]G. Giacchetta, M. Leporini, and B. Marchetti, "Evaluation of the environmental benefits of new high value process for the management of the end of life of thin film photovoltaic modules," 2013.

[109]Health and Safety Impacts of Solar Photovoltaics, NC: North Carolina Clean Energy Technology Center, North Carolina State University, 2017.

[110]C. Miller, Lead Acid Batteries, vol. 3, 2006. 
[111]P. Sinha et al, "Evaluation of potential health and environmental impacts from end-of-life disposal of photovoltaics," Photovoltaics: Synthesis, Applications and Emerging Technologies, pp. 37-51, 2016.

[112]D. Bonnet and P. Meyers. "Cadmium-telluride material for thin film solar cells," J. Mater. Res., vol. 13, No. 10, pp. 2740-2753, 1998.

[113]V. M. Fthenakis, "Overview of potential hazards," Practical Handbook of Photovoltaics: Fundamentals and Applications, Elsevier, 2003, pp. 1-14, ISBN 1-856-17390-9.chVII.

[114]R. Zapf-Gottwick and J. H. Werner, "Leaching hazardous substances out of photovoltaic modules," International Journal of Advanced Applied Physics Research, vol. 2, pp. 7-14, 2015.

[115]V. Fthenakis and K. Zweibel, "CdTe PV: Real and perceived EHS risks," National Center for Photovoltaics and Solar Program Review Meeting, March 24-26, 2003.

[116]H. J. T. Nkuissi, F. K. Konan, B. Hartiti, and J. M. Ndjaka, "Toxic materials used in thin film photovoltaics and their impacts on environment," Reliability and Ecological Aspects of Photovoltaic Modules, 2020.

[117]M. Patterson, A. Turner, M. Sadeghi, and R. Marshall, "Health, safety and environmental aspects of the production and use of CdTe thin film modules." in Proc. the 12th European PV Solar Energy Conference, Amsterdam, 1994, pp. 951-953.

[118]W. Thumm, A. Finke, B. Nuemeier, B. Beck, A. Kettrup, H. Steinberger et al., "Environmental and health aspects of CIS-module production, use and disposal," in Proc. IEEE First World Conference on Photovoltaic Energy Conversion, Hawaii, New York: IEEE, 1994 pp. 262-265.

[119]H. H. S. E. Steinberger, "For CdTe and CIS thin film module operation," IEA Expert Workshop on Environmental Aspects of PV Power Systems, Report No. 97072, 1997, The Netherlands: Utrecht University.

[120]J. Bohland and K. Smigielski, "First solar's CdTe module manufacturing experience; environmental, health and safety results," in Proc. the 28th IEEE Photovoltaic Specialists Conference, pp. 17-22, Anchorage, 2000, pp. 575-578.

[121]V. Fthenakis, K. Zweibel, and P. Moskowitz, Presented at the BNL/NREL Workshop on Photovoltaics and the Environment, Keystone, Colorado, July 23-24, 1998, pp. 33-40

[122]P. R. Salve et al, "Source identification and variation in the chemical composition of rainwater at coastal and industrial areas of India," $J$ Atmos Chem., vol. 68, pp. 183-198, 2011.

[123]Environmental Protection Agency (EPA), Renewable Energy at Mining Sites, 2007.

[124]P. D. Moskowitz, "An overview of environmental, health and safety issues in the photovoltaic industry," Solar Cells and Their Applications, New York, NY: John Wiley \& Sons, Inc., 1995, pp. 391-416.

[125]J. Bohland, T. Dapkus, K. Kamm, and K. Smigielski, "Photovoltaics as hazardous materials," The Recycling Solution, 1998.

[126]P. Gottesfeld and C. R, Cherry, "Lead emissions from solar photovoltaic energy systems in China and India," Energy Policy, vol. 39, pp. 4939-4946, 2011.

[127]W. C. Li and K. K. A. Yeung, "A comprehensive study of green roof performance from environmental perspective," International Journal of Sustainable Built Environment, 2014.

[128]V. M. Fthenakis and P. D. Moskowitz, "Photovoltaics: Environmental health and safety issues and perspectives," Progress in Photovoltaics Research and Applications, vol. 8, pp. 27-38, 2000

[129]R. Kannan, K. C. Leong, R. Osman, H. K. Ho, and C. P. Tso, "Life cycle assessment study of solar PV systems," Solar Energy, vol. 80, no. 5, pp. 555-563, 2006.

[130]A. Báez et al, "Chemical composition of rainwater collected at a southwest site of Mexico City, Mexico," Atm Res, vol. 86, pp. 61-75, 2006.

[131]A. Ramos-Ruiz, J. V. Wilkening, J. A Field, and R. Sierra-Alvarez, "Leaching of cadmium and tellurium from cadmium telluride (CdTe) thin-film solar panels under simulated landfill conditions," J Hazard Mater, 2017, vol. 336, pp. 57-64.

[132]E. A. Alsema and M. J. Wild-Scholten, "Environmental life cycle assessment of advanced silicon solar cell technologies," presented a the 19th European Photovoltaic Solar Energy Conference, Paris, 2004

[133]J. Wood, "Solar energy in Germany," A Market Review, Refocus, vol. 7, no. 3, pp. 24-30, 2006.

[134]P. P. Nain and A. Kumar, "Understanding the possibility of material release from end-of-life solar modules," Renewable Energy, vol. 160, pp. 903-918, 2004

[135]Q. Gao and M. J. Kirisits, "The effect of photovoltaic nanomaterial roofing on harvested rainwater quality," Project Number: USGS 104b Research Grant, 2015.

[136]C. Eberspacher, V. M. Fthenakis, and P. D. Moskowitz, "Environmental, health and safety issues related to commercializing CuInSe2-based photovoltaics," BNL-63334, Brookhaven National Laboratory, Upton, New York, 1996.

[137]W. Reynolds, M. Karmis, and S. Barker, "Assessment of the risks associated with thin film solar panel technology," The Virginia Center for Coal and Energy Research, 2019.

[138]H. Chapman et al., "Characterization of atmospheric deposition as a source of contaminants in urban rainwater tanks," Water Res., vol. 43 , pp. 1630-1640, 2009.

[139]C. Haas et al., "Evidence of avian and possum fecal contamination in rainwater tanks as determined by microbial source tracking approaches," Appl. Environ. Microbiol., vol. 82, pp. 4379-4386, 2016.

Copyright $\odot 2021$ by the authors. This is an open access article distributed under the Creative Commons Attribution License which permits unrestricted use, distribution, and reproduction in any medium, provided the original work is properly cited (CC BY 4.0).

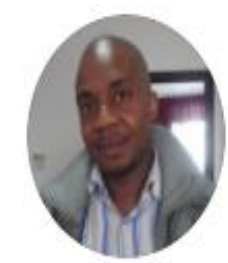

Osayemwenre Gilbert obtained his doctor of science degree from University of Fort Hare, South Africa in 2019, and bachelor of science in physics from University of Benin, Nigeria in 2007. He is a postdoctoral research fellow. His research areas are on renewable energy, photovoltaic solar energy and potable water safety.

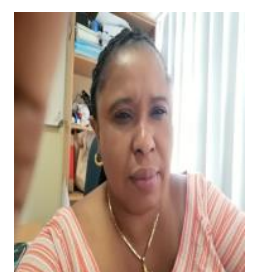

Osibote Adelaja Otolorin completed her undergraduate studies at Ogun State University, Nigeria (now Olabisi Onabanjo University) in physics in 1992 and received her M.Sc. in engineering physics (medical and health physics option) from Obafemi Awolowo University, also in Nigeria in 1999. She obtained her Ph.D (medical physics) from Escola Nacional de Saude Publica (National School of Public Health)-FIOCRUZ, Brazil in 2006. She was a postdoctoral research fellow in the Department of Nuclear Energy, Universidade Federal de Pernambuco (Federal University of Pernambuco), Brazil in 2007 and in the Department of Human Biology (Biomedical Engineering) of University of Cape Town, South Africa in 2008. She was a junior research associate, of the Abdus Salam International Center for Theoretical Physics from 2002 to 2006. Dr. Osibote assumed a faculty position in the Department of Physics, Olabisi Onabanjo University in 1995 and presently in the Department of Mathematics and Physics, Cape Peninsula University of Technology, South Africa. She has carried out research on several areas including irradiation of foodstuffs, quality assurance in diagnostic radiology, developments of algorithms for automated focusing of a microscope for the detection of tuberculosis and measurement of metals and radioactivity in food and environmental fields. She teaches several courses in physics at the University and supervises a number of postgraduate students. 